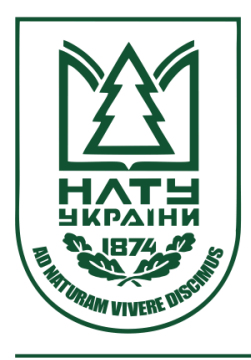

Науковий вісник НЛТУ України Scientific Bulletin of UNFU

https://nv.nltu.edu.ua

https://doi.org/10.15421/40281027

$@ \bowtie$ Correspondence author

Article received 22.10.2018 p.

Article accepted 29.11.2018 p.

V. P. Shlapak

УДК 271.2[2-185:113:53.02]

shlapakwp@gmail.com

В. П. Шлапак

Уманський національний університет садівництва, м. Умань, Україна

\title{
ЖИТТЯ ЛЮДИНИ НА ЗЕМЛІ В КОНТЕКСТІ РУХУ МАТЕРІЇ ТА ЗАКОНІВ ФІЗИКИ
}

Стосовно матерії та законів фізики на підставі матеріалізації антиречовини в речовину розглянуто галактичний кругообіг органічної речовини, зокрема в Сонячній системі. Посилаючись на Біблію, він показує, що життя тваринного світу є на всіх планетах, але на різних їх рівнях і в різних формах, оскільки основою життя тваринного світу є вдосконалення біологічної клітини вищого світу, яка потрапила в Сонячну систему на планету Плутон i, рухаючись по її планетам, формується та вдосконалюється для самостійного життя поза іiі межами. Проведено дослідження прикладної науки Стародавнього світу, що зашифрована в Біблії, яка дає можливість розкрити фізичне явище послідовних близнюків, яке науці невідоме і суть якого не розкрито. Життя органічного світу Землі автор пов'язує з основою руху космічної водневої і сонячної вуглецевої матеpiї, як явищ природи. Зазначено, що воднева матерія, рухаючись з космосу по планетам Сонячної системи, які наділені різною енергетичною густиною, вимушена через життя тваринного світу змінювати свою полярність, рухаючись на Сонце, поставляючи йому водень, як паливо, для його життєдіяльності. Воднева матерія через життя тваринного світу змінює полярність матерії і лише тоді переходить на вищий енергетичний рівень. Вуглецева матерія, як продукт процесу синтезу на Сонці, виноситься квантами світла і розсіюється по планетам своєї системи, утворюючи рослинний світ. Наголошено, що тваринний світ стоїть на вході матерії в Сонячну систему, а рослинний світ - на ії виході. Визначено три форми життя людини на Землі та їі фізіономічні видозміни залежно від рівнів ядрового наповнення: Земного, Місячного і Сонячного. Доведено, що енергетично немовля в утробі матері живе на водневій космічній матерії, яка поступає на земну поверхню 3 ядра Землі. На цій матерії живе і розвивається плід упродовж 270 діб. Народившись, людина переходить жити впродовж природних 120 років на вуглецеву сонячну матерію, яка поступає на земну поверхню місячними циклами руху матерії. Вперше розкрито суть третьої форми життя людини на Землі, коли людина із 120-літного віку переходить жити впродовж 1000 років на вуглецеву матерію, але вже не місячними, а сонячними циклами. Розкриваються властивості людини, переведеної у третю форму життя, та iї інтелектуальний рівень. Наголошено, що Біблія, як інструкція життя людини на Землі, є священною книгою християнського світу, яка має рішення будь-якої проблеми, а тому дає людям надію та впевненість у завтрашньому дню, захищає людство від прогресу, якого людина побоюється.

Ключові слова: Біблія; Сонце; клітина; людина; життя; фізика; еволюція; вік; рух; матерія.

Вступ. Теорії щодо формування та еволюції Сонячної системи складні й різноманітні, на перетині різних наукових дисциплін від астрономії і фізики до геології та планетології. Протягом століть було запропоновано багато теорій утворення Сонячної системи, але тільки у XVIII ст. розвиток цих теорій набув сучасної форми. 3 початком космічної ери з'явилися нові відомості про вигляд і структуру різних об'єктів Сонячної системи, а розвиток фізики дав можливість поглянути на процеси утворення зірок і призвів до перших теорій ї виникнення і руйнування. Відповідно до сучасних уявлень, формування Сонячної системи почалося приблизно 4,6 млрд років тому з гравітаційного колапсу невеликої частини велетенської молекулярної хмари. Більша частина іiі речовини виявилася у гравітаційному центрі колапсу з подальшим утворенням зірки - Сонця. Речовина, що не потрапила до складу центрального тіла, утворила протопланетний диск, з якого надалі сформувалися планети, їхні супутники, астероїди та інші малі тіла Сонячної системи (Sukhonos, 2002; Shevchenko, 2007; Systema, 2018). Нині безліч інформації з цих питань можна знайти в Інтернеті та наукових публікаціях. Однак відповіді на такі прості питання, як: "Навіщо Сонячна система Галактиці та iї робота?" або "Навіщо Сонячній системі планети, а планетам супутники та їх робота" та на безліч іншої інформації відповіді неможна ніде знайти. Водночас відповіді на питання із зазначеної вище тематики можна знайти в Біблії, (Bible, 1988, 1989). Проте, на жаль, наукову інформацію стародавнього світу, яка зашифрована у Біблії у повному обсязі ніхто публічно не висвітлив і не дав відповіді: "Навіщо Біблія насичена цифрами і для чого та що це за віршування з наукової точки зору?".

Наукову інформацію з Біблії, у своєму розумінні, ми розглянули в низці робіт. Серед них: питання з еволюції (історії) розвитку органічного світу та його кругообіг (гігаеволюція як основа еволюції (історії) розвитку органічного світу на галактичному рівні (Shlapak, 2010d), рух антиречовини як основа мегаеволюції (історіi) розвитку органічного світу в Сонячній системі (Shlapak, 2010a), макроеволюція як основа первісного зародження життя і живого на ядровому рівні Землі

Інформація про автора:

Шлапак Володимир Петрович, д-р с.-г. наук, професор, завідувач кафедри лісового господарства. Email: shlapakwp@gmail.com Цитування за ДСТУ: Шлапак В. П. Життя людини на землі в контексті руху матерії та законів фізики. Науковий вісник НЛТУ України. 2018, т. 28, № 10. С. 139-153.

Citation APA: Shlapak, V. P. (2018). Human life on the Earth in the context of matter motion and physical laws. Scientific Bulletin of UNFU, 28(10), 139-153. https://doi.org/10.15421/40281027 
(Shlapak, 2010), мікроеволюція як основа життя і всього живого на Землі (Shlapak, 2010c), наука і релігія: фізика життя на Землі (Shlapak, 2010b), рух матерії у Сонячній системі та на ядровому рівні Землі (Shlapak, 2009b), три форми життя людини на Землі (Shlapak, 2011b) та явищ природи, таких як: денне та нічне світло в контексті науки і релігії (Shlapak, 2009e), відкриті питання у виникненні грози та іiі наслідків (Shlapak, 2011a), горіння як процес видалення генетичного коду з органічного і неорганічного світу (Shlapak \& Shlapak, 2010) та інші.

У Першій книзі Мойсея: Буття в Главі 5 "Родовід Адама і потомство Ciфа" (Bible, 1988, 1989) у вірші 2124 засвідчено: "I жив Енох 65 літ, та й породив Метушалаха. І ходив він з богом потому, як породив він Метушалаха, 300 літ. I породив він синів і дочок. А всіх Енохових днів було 365 літ. Та й помер він. І ходив Енох з богом. I не стало його, бо забрав його Бог". А Іоанн Богослов у Об'явленні в Главі 20 "Перше воскресіння і тисячолітнє царство Христове" у вірші 4 вказує: "I вони ожили і изарювали з Христом тисячу років", а у 6 вірші розшифровує: "Блаженний $і$ святий, хто має частку в периому воскресінні! Над ними друга смерть друга не матиме влади, але вони будуть священиками Бога $i$ Христа, і ияарюватимуть з Ним тисячу років". А чи розуміємо записане з погляду прикладної науки. Відповідь однозначна - Нi! Тому й донині немає єдиної відповіді. Водночас у цьому вірші Іоанн Богослов пише про воскреслу людину із 120-літнього віку, людини 3 "Віри" $\left(T_{2}^{1}\right)$, яка може бути переведена людиною із "Закону" $\left(T_{2}^{2}\right)$ у третю форму життя людини з 1000-літнім віком $\left(T_{3}\right)$, яка "стане священиком Бога і Христа". Ось чому Біблія Ісуса Христа називає "Сином божим" і описує його творіння, одночасно підкреслюючи про можливість існування на Землі "Сина людського". Якщо звичайна людина через ритуал буде переведена на 1000-літнє життя, вона набуде властивостей "Сина божого", то буде царювати 1000 років з "Богом $і$ Христом". Тут же виникає запитання: "Це стосується живої чи мертвої людини?" Тобто їі життя на Землі в стані речовини чи ії подальше неземне життя у стані антиречовини (Shlapak, 2008, 2009d, 2011b; Shlapak \& Shlapak, 2010). Відповідь на ці питання знаходимо у Главі 1 "Соборного Послання Святого Апостола Іуди" у вірші 12, який дає пояснення, що людина 3 1000-літнім життям, або за Біблією "двічі померлі", має простір для життя на Землі, вказуючи, що з початком нашої ери "двічі померлi, викоренені" (Bible, 1989). Отже, йдеться про звичайну земну людину, яка, використавши механізм другого народження, була переведена зі 120-літнього віку на 1000-літне життя. А це третя форма життя людини на Землі $\left(T_{3}\right)$. Це астральне безсмертя. Тому виникає запитання: "Що не так було зроблено людиною зі 1000літнім віком, що було прийнято рішення іiї знищити i, як вказує Іуда, взагалі як "двічі померлих", викорінити навіть із структури будови земного суспільства?". Це явище академічній науці невідоме, а тому й не вивчається. У цьому доречно звернути увагу на слова розмови Ісуса Христа з Никодимом, Біблія, Свангелія від святого Івана (Bible, 1988), глава 3, вірш 4: "Як може людина родитися, будучи старою? Хіба може вона увійти до утроби своєї матері $i$ знову родитись?". У цьому відповідь необхідно шукати не в першоджерелах і тлумаченнях вчених, які впродовж тисячоліть вивчали і вивчають ці питання та ставлять під сумнів подібну інформацію і цим самим одночасно заперечуючи істотно важливу технологічну біблійну інформацію, а відповідь знаходимо в Біблії. Євангелія від святого Івана (Bible, 1988), глава 3, вірш 27: "Не може людина нічого приймати на себе, якщо їй не буде дано з неба". Водночас, вчитуючись у Біблію, стає зрозумілим, що останній месія - Ісус Христос, якого народила діва Марія, хрестив Іоано Хреститель, на нашу думку, це прообрази Олександра Македонського, його матері Олімпіади та філософа Аристотеля.

У роботі роз'яснюємо, що Біблія розкриває структуру будови земного суспільства, вказуючи на існування трьох людських родів. Тому Аристотель, за Біблією, людина із "Закону" $\left(T_{2}^{2}\right)$, який володів механізмом запуску і процесом переходу людини з 120-літнього віку в третю форму життя людини $з$ 1000-літнім віком. Доречно наголосити, що людина у другій формі життя на Землі за Біблією має декілька віків. Перший - 120 років. Біблія (Bible, 1989), Книга Буття, розділ 6, вірш 3: "Не буде Мій Дух перемагатися в людині навіки, - бо блудить вона. Вона тіло, і дні ї̈ будуть, сто і двадиять літ". Це вік людині даний природою. Другий - 70 років, а за доброго здоров'я 80. Біблія (Bible, 1989), Книга Псалмів, Псалом 89, вірш 10 "Дні літ наших - у них сімдесят літ, а при силах - вісімдесят літ, $і$ гордощі їхністраждання і марнота, бо все швидко минає, $і$ ми відлітаємо ...". Третій - Біблія (Bible, 1989), Псалом 55, вірш 24: "...Люди чинів кривавих й обмани, - бодай своїх днів вони не дожили, навіть до половини..." Два останні $є$ не природним віком і залежать від структури будови суспільства. Тут необхідно пояснити словами Біблії. Книга Буття (Bible, 1989), розділ 25, вірш 23: I промовив до неї Господь: "Два племені в утробі твоїй $i$ два народи з твого нутра будуть виділені, і стане сильніший народ від народу, і старший молодшому буде служити". Ці три людські роди показані на іконі "Святої тройці" - людина із "Закону", яка тримає "Землю", їх Біблія називає ще "гладенькі" та "пастухи" $\left(T_{2}^{2}\right)$, людина з "Віри", яка тримає хрест і Біблію, їх Біблія називає "волохатенькі" й "овечки" $\left(T_{2}^{1}\right)$ та третя форма життя в образі голуба - "Месії". Біблія "Месію" називає "Сином Божим", або "двічі померлим" ( $\left.\mathrm{T}_{3}\right)$. Це підтверджує те, що в природі існує механізм переводу людини із 120літнього віку в 1000-літній вік і лише людей з "Віри", оскільки вони живуть в єднанні 3 природою $\left(T_{2}^{1}\right)$. Друга форма життя людини, людини із "Закону" $\left(T_{2}^{2}\right)$, не може перейти на 1000-літнє життя, оскільки в неї розірване єднання з природою через зривання (оскоплення) захисної оболонки 3 організму людини, тобто оголення ядрової частини організму людини. Так говорить Біблія (Bible, 1989), Свангелія від Святого Матвія, розділ 19, вірш 11, 12: а він їм відказав: "Це слово вміщають не всі, але ті кому дано". "Бо бувають скопиі, щуо з утроби щзе материної народилися так; $\epsilon$ й скопиі, щзо їх люди оскопили, і є скопиі, щчо самі оскопили себе ради Царства Небесного. Хто може вмістити, - Нехай вмісmuть". Про цю форму життя Біблія (Bible, 1989), Свангелія від Святого Луки, розділ 5, вірш 10 говорить так: I сказав Ісус Симонові "Не лякайтесь, - від изього часу ти будеш ловити людей!", а в Книзі Буття, розділ 3, вірші 15 написано: "I Я покладу ворожнечу між тобою й 
між жінкою, між насінням твоїм і насінням ї. Воно зітре тобі голову, а ти будеш жалити його в п'яту". Це енергетичні вампіри (Beili \& Seddon, 1998). Водночас Біблія регламентує їхнє втручання в енергетику, життя людей із "Віри", вказуючи на вік можливого енергетичного втручання. Біблія (Bible, 1989), розділ 4, вірші 34-40, цитуємо вірш 39: "Від віку 30 літ і вище, $i$ аж до віку п'ятдесяти літ, кожен, хто входить до відділу на службу скинії заповіту ...". Тому подаємо біблійні висловлювання 3 цього приводу. Біблія (Bible, 1988), Свангелія від Іоанна, глава 3, вірш 27: Іоанн сказав у відповідь: "Не може людина нічого приймати на себе, якщзо їй не буде дано з неба", а у главі 7, віршах 16 і 17 вказано, що Ісус, відповідаючи їм, сказав: "Наука моя - не Моя, а Того Хто послав Мене. Коли хоче хто волю чинити Його, той довідається про науку, чи від Бога вона, чи від Себе Самого кажу Я", а у вірші 18 написано: "Хто говорить від себе самого, той власної слави шукає, а Хто слави шукає Того, Хто послав Його, Той правдивий, - $і$ в ньому неправди немає". До того ж у Біблії є звернення до представників людей із "Закону". У книзі Пророка Єремії, розділ 3, вірш $22 \epsilon$ такі слова: "Верніться, невірні сини, усі вамі відступства Я вилікую!". У цьому доречно акцентувати, що людина, яка буде переведена на 1000-літнє життя, може привести суспільство в однорідне середовище, але ліпше в контрольоване суспільство, оскільки рушійною силою розвитку науково-технічного прогресу є люди із "Закону". Водночас доречно визнати, що В. В. Курляндський (Kurliandskii, 2001) про існування на Землі трьох людських родів, досліджуючи "мімікрію", дуже чітко в образах метелика, птаха і змія подав варіанти їхньої взаємодії, засвідчили, що людина із "Закону" здатна запустити механізм послідовного народження людини з "Віри", яка здійснить перехід на 1000-літне життя та перейде у третю форму життя людини на Землі, яка прийме образ "Сина Божого", а на справді будучи лише "Сином людським". Варто зазначити, що В. В. Курляндський (Kurliandskii, 2001), володіючи механізмом переходу людини в третю форму життя на Землі, у цитуванні листа "Преподобним сеньйорам" вказує про відповідальність людини із "Закону" і його сім'ї за запуск механізму переходу людини на 1000 літнє життя. Що хотів цим сказати автор? Важко судити! Однак з біблійного погляду, якщо припустити, що людині з "Віри" можна встановлювати вік у 30, 50, 70, 80 чи 95 років чи будь-який інший за природного в 120 років, то механізм запуску в третю форму життя людини знаходиться в накладанні ритуалу людьми із "Закону" за рівнем ними визначеного віку для "обраного народу", а помилка допущена за накладання ритуалу чи свідоме розірвання протікання ритуального процесу дає можливість у конкретно "відібраної людини" запустити механізм переходу на 1000-літнє життя. "Відібрані люди" - це люди з "Віри".

Водночас необхідно засвідчити, що за допомогою алхімії уже з III-IV ст. н. е. академічні науковці, як осколок від магічної науки Стародавнього світу, намагаються самостійно відшукати еліксир молодості, або як ми сьогодні говоримо, за допомогою генної інженерії отримати формулу довговічності людського життя та вічного життя. Але, втративши наукові здобутки Стародавнього світу, світу пророка Мойсея, Аристотеля, Піфагора i недооцінивши вчення Галілео Галілея,
В. I. Вернадського та заплутавшись в еволюційних процесах розвитку (історії) органічного світу Землі, зокрема й походження людини, затрачаючи величезні матеріальні ресурси, так і не змогли наблизитися до біблійного віку життя людини, визначеного природою у 120 років. Однак, за середньосвітового терміну життя людей у 65 років, наприклад в Ісландії, Китаї (Гонконг), Ліхтенштейні, Японії, Ізраїлю та інших більш розвинених країнах, такий вік становить 80-95 років, а в Ботсвані, Лесото - 34, Сьєрі-Леоні - 39, Мозамбіку - 41. Серед краін СНГ також різні дані: в Узбекистані - 70, Туркменії 67, Азербайджані, Вірменії, Грузії - 75, Латвії і Естонії - 77, в Російській Федерації - 59, Молдові - 65, а в Україні - 63 роки (Zhizn, 2018). Ці роки наочно вказують на врегульованість "встановленої планки" терміну людського життя у різних країнах світу, але варто зазначити, що Біблія не пов'язує залежність віку людини 3 навколишнім природним середовищем та його забрудненням, що нині постійно нав'язується людині. Проте пошуки довговічності життя, з використанням надбаного людством на початку третього тисячоліття науковотехнічного прогресу, особливої актуальності набули зараз. Але ці пошуки є малоефективними, оскільки сама ідея є оманою, яка неупереджено зведена людиною лише до сповільнення ефекту старіння, а не продовження iii віку (Shlapak, 2009c).

Виділення не вирішених раніше частин загальної проблеми. У стародавньому Єгипті, за 4-8 тис. років до нашої ери, Гор вважався богом Сонця. Він - Сонце в образі людини. Гора народила 25 грудня діва Марія. Коли він народився загорілася зірка на сході, за допомогою якої три царі знайшли місце народження спасителя. У віці 12 років він учив дітей багатія, у віці 30 років прийняв духовну посвяту від Онуфа. У Гора було 12 учнів, 3 якими він подорожував, творячи чудеса зціляв хворих і ходив по воді. Гор був відомий під багатьма алегоричними іменами, такими як: істина, світло, син божий, пастир божий, агнець господній та ін. Після зради Тифона Гора розп'яли на хресті, поховали на 3-му дні, а потім він воскрес. Чи був Гор першим чи ні, але ці ж риси трапляються в багатьох культурах світу, у багатьох інших богів і їх можна віднести до єдиного міфу. Проте варто також акцентувати, що Гор, як бог Сонця, був покровителем влади фараона і його вважали земним втіленням. Гор - син Осіріса й Ісіди - відображався у вигляді сокола чи людини з головою сокола. Заслуговують на увагу також фрігійський бог Атіс, індійський бог Кришна, грецький бог Діоніс, перський бог Мітра. Так, фрігійського бога Атіса (1200 років до н.е.) народила діва Нана 25 грудня, був розп'ятий i, пробувши в могилі три дні, воскрес. Індійського бога Кришну (900 років до н. е.) народила діва, яку звали Девакі. Його прихід позначила зірка на сході, він творив чудеса зі своїми учнями, а після смерті воскрес. Грецького бога Діоніса (500 років до н. е.) народила діва 25 грудня. Подорожував і вчив людей, творячи такі чудеса, як перетворення води у вино. Його називали царем царів, сином божим, альфою й омегою та іншими епітетами, а після смерті він воскрес. Перського бога Мітру (1200 років до н. е.) народила діва 25 грудня. У нього було 12 учнів, він творив чудеса, а після смерті його поховали, а за три дні він воскрес. Його називали істиною, світлом та іншими іменами. У дійсності багато спасителів, існуючи в різні часи, по усьому світу, попа- 
дають під це правило. Тому виникають запитання: "Звідки узялися ці схожі риси? Чому діва народила 25 грудня? Чому він був мертвий три дні, а потім воскрес? Чому 12 учнів і послідовників?" (Vocabulary, 1980, 1989; Vremia, 2018).

Щоб зрозуміти таку закономірність давайте звернемося до останнього Сонячного "Месії". Ісуса Христа народила діва Марія, 25 грудня у Віфлеємі (Bible, 1988, 1989; Vocabulary, 1989; Vremia, 2018). Його народження ознаменувалося зіркою на сході, за якою його місце народження знайшли три волхви. Він учив дітей у 12 років, а коли йому було 30 - років його хрестив Іоанн Хреститель. Після хрещення Ісус Христос почав своє служіння. В Ісуса було 12 учнів, з якими він подорожував, творячи чудеса. Він зціляв хворих, ходив по воді, оживлював мертвих. Він був відомий як цар царів, син божий, альфа й омега, агнець господній, великан, двічі народжений, двічі померлий. Після зрадництва своїм учнем Іудою, який продав його за 30 срібляків, Ісуса Христа розіп'яли, поховали на три дні, а потім він воскрес і піднісся на небеса.

Отож, в алегоричних образах єгипетського бога Гоpa, фрігійського бога Атіса, індійського бога Кришни, грецького бога Діоніса, перського бога Мітри та нинішнього християнського бога Ісуса Христа простежуємо певну групу ідентичних закономірностей, які не мають цілісного наукового пояснення. Водночас необхідно відзначити, що критичному аналізу піддається список численних рятівників різних часів і народів, схожих за характеристиками з Ісусом Христом. Порушуючи питання методології порівняння християнства i язичницьких містерій, різко критикують спроби пошуку поверхової схожості (внаслідок ігнорування відмінностей), яка "виглядає правдоподібно за рахунок вибіркових описів", але "випаровуються при зіставленні 3 оригінальними текстами". Окремі критики відкидають ідею запозичення християнства 3 культів Осіріса, Мітри, Орфея, Аттіса й Адоніса (Vremia, 2018). Однак, як вказує В. В. Курляндський (Kurliandskii, 2001), Синагога і церква книгу "Буття" хоча й приписують Мойсею, як і інші книги П'ятикнижжя, а насправді, текст цих книг сходить до Кодексу Сгипетських жерців, наукові фрагменти якого належать до 1500-8000 років до Різдва Христового. Тобто, на певному етапі розвитку цивілізації відбувалися, незалежно від віросповідання, крадіжки технології створення "Сина людського - Месії" - переведення людини з "Віри" у третю форму життя, яка забезпечила як розвиток, так і занепад сімох наймогутніших цивілізацій: єгипетської, ассірійської, вавилонської, медоперської, візантійської, грецької та римської, нині володіє світом англо-американська цивілізація, засновником якої залишається ось уже впродовж 3500 тисяч років неперевершений геній, пророк Мойсей. Ось в чому суть схожості Єгипетського бога Гора, фрігійського бога Атіса, індійського бога Кришни, грецького бога Діоніса, перського бога Мітри та нинішнього християнського бога Ісуса Христа, а не належність богів Осіріса, Мітри, Орфея, Аттіса і Адоніса до християнства. Тому вважаємо, що людину, яка житиме в третій формі та називатиметься "Месією", необхідно штучно створити не як реформатора будови суспільства на Землі, а як провідника людства 3 одного тисячоліття в наступне тисячоліття.

Обговорення результатів дослідження. Безліч наукової інформації, філософських течій, суперечностей, які розділяли і розділяють суспільство, пов'язано як 3 еволюційними думками, що викладені у працях найвідоміших пророків, філософів та природознавців, так і $з$ пошуками довговічності людського життя, вічного життя. Вчені всього світу, народні цілителі, духовні наставники пробують знайти різні способи продовження життя за допомогою дієти, спеціального психологічного тренування, укріплення сили волі, сили духу за допомогою молитви, постів, медицини як традиційної, так і нетрадиційної. Але ці пошуки є малоефективними, оскільки вони неупереджено зведені людиною, з одного боку, до обмеження еволюційних процесів (історії) розвитку органічного світу від простого до складного і лише на Землі, які є проблематичними в контексті науки і логіки (Korniienko, 1999), а з іншого - лише до сповільнення ефекту старіння, а не продовження віку людини. Причина відома. Людина не може зрозуміти навколишній світ швидше через того, що ми живемо в розімкнутому просторі, а тому нам невідомий загальний світовий кругообіг органічної речовини як у стані речовини, так і антиречовини. Наше життя відбувається ніби за нескінченною прямою лінією, в якої немає початку і кінця.

Однак у своїх працях вперше розкриваємо суть еволюції (історії) розвитку органічного світу Землі, як космічного явища (Shlapak, 2010a, 2009b; Shlapak, 2008, 2010, 2010c, 2010d, 2011a), як складової загального галактичного кругообігу органічної речовини, речниками якої були пророк Мойсей, вчені-філософи Платон, Аристотель, Піфагор, Галілео Галілей та В. І. Вернадський (Vernadskyi, 2005; Vocabulary, 1989). Так, пророк Мойсей у першій книзі Буття у главі 5 "Родовід Адама i потомство Сіва", у віршах 1-32 (Bible, 1988) вперше в алегоричній формі подав сучасну будову Сонячної системи і надав планетам людські імена (Shlapak, 2009a). Цим самим ствердив, що на всіх планетах є людське життя, яке підпорядковане сонячному еволюційному розвитку, а не земному, що на кожній планеті людиноподібні види можуть знаходитися і розвиватися в найрізноманітніших формах та зонах планет і бути лише фізіономічно різними. Він вперше вказав на існування головних енергетичних рівнів та їх підрівнів на кожній планеті. Неоціненний внесок в еволюційне вчення зробив Піфагор (Vocabulary, 1989), вчення якого в доісторичній Греції трактувалось, виходячи з уявлення про числа, як основи всього існуючого. Піфагор вказував, що числові співвідношення - це джерело гармонії космосу, а структурою їх є фізична, геометрична й акустична єдність. Він вперше довів, що в Сонячній системі все побудовано за десятинною системою. Це дало нам змогу вийти на генетичний код Сонячної системи, який у вихровому полі за десятинною системою обліку має вигляд: 10864213579. А оскільки ми живемо в період після першої Сонячної катастрофи, де наш світ займає другу позицію в будові Сонячної системи, перейшовши 3 десятого на дев'ятий енергетичний рівень, тому генетичний код Сонячної системи також перейшов на дев'ятизначний рівень: 864213579 (Shlapak, 2008).

За науковою інформацією з Біблії (Bible, 1988), у четвертій книзі Мойсея: Числа, главі 33, вірші 39, вказується максимально можливий термін перебування, оренди клітин, які належать до простору вищого порядку, ніж наш, генетичним волокном людини на Землі в живому 120 років і неживому 3 роки стані: "Арон був віку 123 роки тай помер" (Bible, 1988, 1989) та Закону 
Галілео Галілея (Vocabulary, 1989) "Про складання рухів", визначаємо, що максимальний термін перебування (оренди клітин) генетичним волокном людини в Сонячній системі становить на Меркурію 1 рік, а на інших планетах відповідно: на Венері - 12; на Землі - 123; на Марсі - 1234; на Юпітері -12345; на Сатурні - 123456; на Урані-1234567; на Нептуні - 12345678; на Плутоні - 123456789 років. Отже, від терміну оренди клітин, ядрових клітин космічного походження, клітин не нашого світу, ми знаємо максимальну тривалість нашого життя, тривалість перебування генетичного волокна людини на всіх планетах Сонячної системи, природного життя. Сонячна система у десятинний системі обліку в першій позиції життя того світу, до катастрофи, проіснувала майже 12,5 мільярдів років, а у другій позиції будови генетичному вектору людини, на рух по маршруту Плутон $\rightarrow$ Сонце, природа відвела 137,2 мільйони років. Це означає, що за цей термін генетичне волокно людського виду (Homo sapiens) повинно бути витягнене $з$ ядер усіх планет і відправлене для формування клітини, здатної для самостійного життя поза межами Сонячної системи. Проте впродовж життя Сонячної системи, а це 12647614479 років (12,65 млрд років), таких зупинок дев'ять, а в нашому розумінні катастроф, яким передуватиме щоразу зникнення однієї з планет. Тому не важко порахувати, що у третій позиції вона проживе 13717416 років, відповідно у четвертій 1371738 ; у п'ятій - 137171; у шостій - 13715; у сьомій 15085 ; у восьмій - 136; в дев'ятій - 13 років. I на 13 році завершить своє життя, тобто залишилося 27587159 років. Сонце завершить своє життя у стані антиречовини темної матерії, так званої "Чорної діри", яка поглине всі залишки матерії Сонячної системи, висипавши прах з іiі планет у простір зниклого, віджитого галактичного біологічного життя, видозміниться і в його ж просторі завершить своє життя.

А людство, як зазначає В. I. Вернадський (Vernadskyi, 2005), як жива речовина, нерозривно пов'язана з матеріально-енергетичними процесами певної геологічної оболонки Землі, з іiї біосферою, яка є планетарним явищем космічного характеру. Тому потрібно зважати на те, що життя (живі організми) реально існують не тільки на одній нашій планеті, не тільки в земній біосфері. Це встановлено, безсумнівно, для всіх так званих "земних планет", тобто для Меркурія, Венери, Землі, Марса.

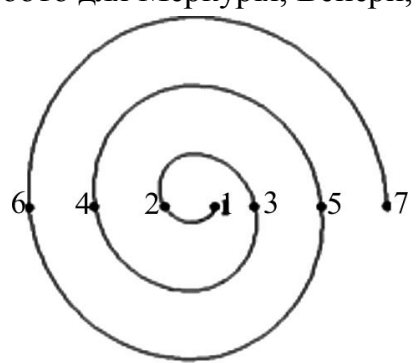

Pис. 1. Рух матерії в Сонячній системі

Отже, використовуючи знання пророка Мойсея, Піфагора, Галілео Галілея та В. І. Вернадського, ми дійшли висновку, що число 864213579 - це код Сонячної системи нашого світу, де Земля в'яже в цьому вектоpi сьому клітину, оскільки знаходиться на сьомому місці від Плутона. Тому генетичний вектор життя, який заходить на Землю з Марса, має вигляд: $6^{1}-642.135-7$. Отже, в оболонці шість зав'яжеться сьома ядрова клітина нашого життя і він у вигляді: $7^{1}-642.1357-8^{1}$ роз- почне рух на Венеру. Тому неважко передбачити, що код 642.135 це критична місткість для матерії ядра й оболонки у земної людини (рис. 1). Земне ядро може мати тільки три рівні в оболонці та сім рівнів у ядрі Землі. Тоді код біологічних клітин Землі, число - 37. Отож, місткість ядра клітини не може перевищити число 777, а місткість оболонки 333. Склавши парні і непарні числа генетичного коду отримаємо: $642+135=777$. Генетичний код дає сумарне наповнення ядра земної клітини по його рівень. Тоді число: 642 - це наповнення головного рівня ядра, а 135 - це наповнення забороненої зони ядра. Водночас якщо одна із зон ядра клітини досягне критичного значення, то людиноподібна істота (біологічна клітина) загине, або здійснить якийсь скачок. А це так. Тому неважко порахувати критичний момент генетичного волокна людського життя залежно від рівнів ядрового наповнення: Земного, Місячного і Сонячного.

Життя тваринного світу, зокрема й людини, пов'язане 3 виникненням яйцеклітини. Саме 3 цього моменту розпочинається новий виток руху і матеріалізації антиречовини галактичної матерії видовим різноманіттям тваринного світу, зокрема й людини, яка потрапила еволюційним шляхом із галактичного світу на Землю, рухаючись послідовно по планетам Сонячної системи та вдосконалюючись. Для розкриття суті третьої форми життя людини на Землі як фізичного явища природи, на нашу думку, доцільно розібратися 3 рівнями ядрового наповнення Землі (рис. 2).

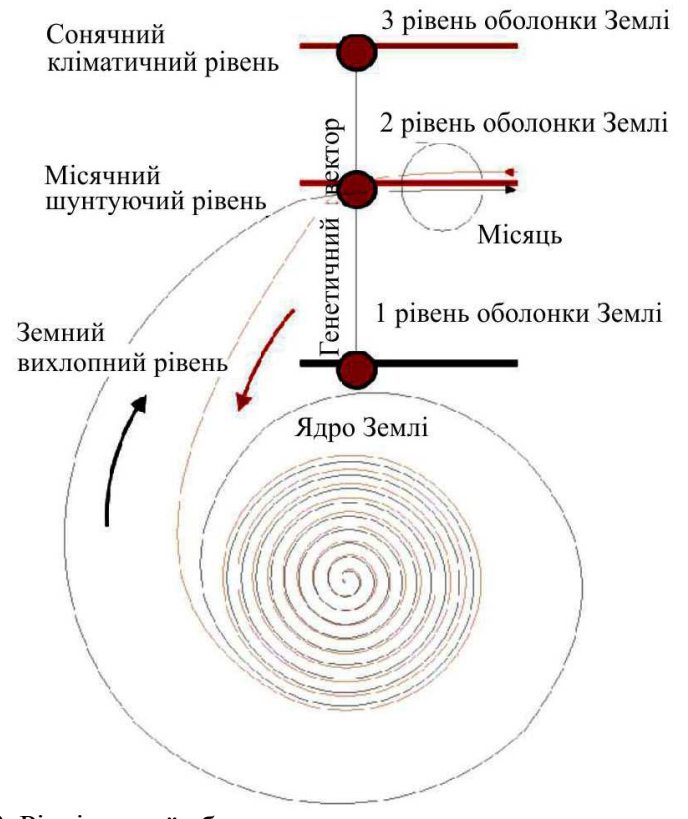

Рис. 2. Рівні земної оболонки

Як видно з рис. 2, Земля має спіраль із трьох енергетичних рівнів. Це означає, що на Землі існують три рівні ядрового наповнення: Земний, Місячний і Сонячний. Найнижчим рівнем (витоком матерії) є Земний, потім йде Місячний і Сонячний. Якщо пов'язати життя людини на поверхні Землі з її генетичним вектором, то зауважимо, що життя залежить від рівнів земних оболонок, на енергетичній матерії яких людина живе і розвивається. Однак варто акцентувати, що перший (земний) і другий (місячний) рівні є складовою фізичної та енергетичної будови Землі, де густина іiі рівня становить $3 \times 10^{7}$ космічних одиниць, а фізичні та біологічні властивості як живої, так і неживої матерії пов'язані з яви- 
щами, які відбуваються на Землі і за якими можна спостерігати. На сонячний рівень (третій рівень оболонки) Земля впливу не здійснює, оскільки це не іiі рівень (простір), а густина Сонця, його енергія виражається числом $10^{10}$ космічних одиниць.

Отже, Земля, як макроклітина для Сонячної системи (мегаклітини), є iї механізмом, який задіяний у транспортуванні генетичного волокна (матерії) 3 додатного простору ядра Землі у від'ємний простір іії оболонки, на поверхню земної кори, де проживає тваринний світ, зокрема й людина, та первісне зародження на видових рівнях живого 3 неживого, матеріалізації антиречовини в речовину (Vernadskyi, 2005; Kurliandskii, 2001; Lazarev, 2003; Lindblad, 1991; Shlapak, 2009a, 2009b, 2010b).

Доречно також акцентувати, як вказує $С$. П. Комрат (Komrat, 2008), що видимі речі є лише тінь і контури речей, яких людина не може бачити. Цю ж думку підтверджує і Платон, підкреслюючи, що все, що існує на Землі, є тінь того, що існує у вищих сферах (Vocabulary, 1989). У кабалістичних книгах, простежують міркування про те, що кожний предмет на Землі або в нашій Вселений є "Тінню" вічного Світла або Божества (Zhe$\mathrm{rar}, 2004)$. Такої ж думки дотримується В. В. Курляндський (Kurliandskii, 2001). Заслуговує на увагу думка А. С. Лазарева (Lazarev, 2003), де в передмові виступили А. І. Бондаренко, I. В. Подолін, які стоять на біблійній позиції енергетичної будови людини 3 плоті та духу. Проте позиція Біблії (Bible, 1988, 1989) більш об'ємна і зведена до того, що людина на Землі має зовнішність людиноподібної істоти вищого галактичного світу і що має тіло і дух як єдине ціле, двохначальне, зокрема, вживаючи терміни - "Син людський" i "Син божий", тлінне і вічне, тіло і дух. А в нашому розумінні це, не що інше, як матеріалізація антиречовини в речовину (Shlapak, 2009c, 2009d), що є двохначалом земного і космічного, тобто єдиним цілим у будові людини - речовина, яка $є$ тлінною, короткочасною, земною та антиречовина, яка $\epsilon$ вічною, постійною, космічною. Про це перша книга Мойсея Буття, глава 1, вірш 27 говорить: "I створив Бог людину по образу своєму, по образу Божому створив ї̈; чоловіка і жінку створив їх", а у вірші 7, глави 2 записано: "I створив Господь Бог людину із пороху земного, $i$ вдихнув у лище його дихання життя, $i$ стала людина душею жсиою". Так, на земному, першому рівні оболонки Землі антиречовина матеріалізує ембріон як самостійну і незалежну форму життя. Ембріон, який візуально на першій із трьох стадії зародкової схожості хребетних тварин і людини, що належать до різних систематичних груп: риб, амфібій (саламандра), рептилій (черепаха), ссавців (пацюк, людина), нічим не відрізняється один від одного (Korniienko, 1999). Тому вважаємо, що природа використовує механізм, який у процесі росту і розвитку ембріона приводить до видозміни, нововидоутворення тваринного світу, зокрема й немовляти (людини), але за мікроеволюційними законами: все живе 3 живого і собі подібного (Vernadskyi, 2005; Shlapak, 2010d). Це перше народження людини $\left(T_{1}\right)$. Але в природі існує і друге народження людей, тобто людини, яка живе в унісоні з природою, у другій формі життя людини на Землі $\left(T_{2}^{1}\right)$ і людини, у якої розірване єднання 3 природою $\left(T_{2}^{2}\right)$. Саме людина, у якої розірване єднання з природою, володіє механізмом, за допомогою якого можна видозмінити зовнішній вид людини 3 терміном життя у 120 років $\left(T_{2}^{1}\right)$ і перевести іiі у третю форму $\left(T_{3}\right)$ з терміном життя людини на Землі в 1000 років. Отже, здійснити переведення людини 3 другої форми життя $\left(T_{2}^{1}\right)$ у третю форму життя $\left(T_{3}\right)$ може лише людина 3 другої форми життя $\left(T_{2}^{2}\right)$ - культова людина, людина із "Закону", яка здатна енергетично вмішуватися в життя людини з "Віри" $\left(T_{2}^{1}\right)$. Доречно зазначити, що у 2001 р. В.В.Курляндський (Kurliandskii, $2001)$ у листі "Преподобним сеньйорам", виду з другої форми життя $\left(T_{2}^{1}\right)$ не рекомендує запускати третю форму життя людини на Землі $\left(T_{3}\right)$, так званого "Сина людського" або "Месію".

Вперше еволюцію (історію розвитку) органічного світу землі написав Чарльз Дарвін (Darvin, 1991), де показав зміну видів рослин і тварин, їхнє природне походження від більш ранніх видів. Отже, коли ми говоримо, посилаючись на Чарльза Дарвіна, що еволюція здійснюється унаслідок взаємодії трьох основних чинників: мінливості, спадковості та природного добору, то повинні мову вести не про гіпотетичний палеонтологічний ряд попередників людини: дріопітеки ("дріос" дерево, "пітекус" - мавпа; тобто деревна мавпа) $\rightarrow$ рамапітеки ("рама" - ім'я міфічного індійського князя) $\rightarrow$ австралопітеки ("австралос" - південний, тобто південна мавпа) $\rightarrow$ людина вміла $\rightarrow$ найдавніші люди, або архантропи (до них відносять: пітекантропа "мавполюдина", синантропа "китайську людину", гейдельберзьку людину, атлантропа) $\rightarrow$ нові люди, або неоантропи, або кроманьйонці, або Hoто sapiens (кроманьйонцями називають лише викопних людей, які мають всі риси Ноmo sapiens), а про видовий ряд незалежних людиноподібних істот, оскільки еволюції людини в природі не існує. Матерія у вигляді волокна з Галактики, на якому нанесені потенційні точки біологічного виду тваринного світу, попадаючи в Сонячну систему, рухається по іiі планетам і зароджується на видовому рівні життя тваринного світу, де діє закон збереження матерії. Матерія, зникнувши на Землі через нанесені потенційні точки, які залишені від життя тваринного світу і не лише його, на генетичному волокні галактичної матерії, потрапивши на Венеру, зародить життя тваринного світу чи іншого об'єкта в масі й об'ємі, яким він був на Землі. Так діє закон збереження матерії, а в межах Землі він не діє. Наприклад, згоріли дрова, зіржавіло залізо. Де все поділося? Коли за законом повинна зберегтися їхня маса, а, окрім попелу, нічого не збереглося.

Дослова, таку ж позицію висвітлено і в Біблії. Так, перша книга Мойсея: Буття, глава 1, вірш 24: "I сказав Бог: нехай призведе земля душу живу по роду їх, скотину, $i$ гадів, $i$ звірів земних по роду їх" (Bible, 1988, 1989). Підтвердженням цього $\epsilon$ висновок Ян Ліндблада (Lindblad, 1991), який вказує, що: "У печерах гори Кармель на березі Середземного моря виявлено скелети, які справляють враження змішування неандертальців, які тут проживали, з кроманьйонцями, що вторглися туди". Але навіть якби між кроманьйонцем і неандерталкою могли виникнути зв'язки, то складне поєднання хромосом стало б на заваді потомства. Гібрид не отримав би продовження, оскільки гібриди від різних видів безплідні. Такої ж думки й апостол Іуда, вказуючи, що "гібриди безплідні" (Bible, 1988, 1989). Тому, якщо висновок Чарльза Дарвіна про взаємодію трьох основних чинників: мінливості, спадковості та природного добору, застосувати на видовому рівні в ряду попередників людини: антиречовина людини $\rightarrow$ ембріон людини $\rightarrow$ 
людина 3 120-річним життям $\rightarrow$ людина 3 1000-літнім життям, то, без сумніву, необхідно визнати, що це так і що, завдяки спадковості, мінливості та безперервної дії природного добору, організми в процесі еволюції накопичують щоразу нові пристосувальні ознаки, що зрештою веде до утворення нових видів (нововидоутворення), але на видовому, а не на міжвидовому рівнях, де відбувається лише фізіономічна видозміна залежно від природних та кліматичних чинників, а не нововидоутворення. Тому доречно розглянути ці земні рівні докладніше в контексті життя людини на Землі з погляду руху матерії та законів фізики.

Земний рівень оболонки Землі. Із зазначеного вище виходить, що сонячна матерія на земному рівні відсутня. Це вихлопний рівень (див. рис. 2), який замикає ланцюжок земної спіралі кругообігу речовини. Сонячна матерія на цей рівень заноситься лише генетичними векторами біологічних комплексів тваринного і рослинного світу. Тому побудуємо діаграму земного кругообігу біологічної системи (рис. 3).

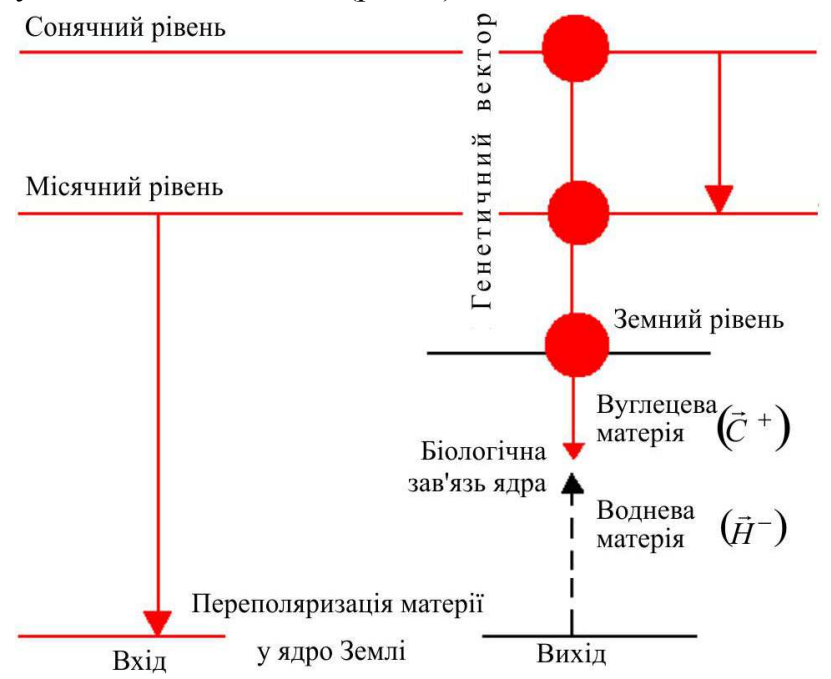

Рис. 3. Спіраль біологічного кругообігу на Землі, утворена на зав'язі біологічного ядра механізмом утворення голограм

3 рис. 3 видно, що земний рівень працює лише для утворення ядрової зав'язі для біологічного комплексу і заповнення негативною $(-)$ водневою $\left(\vec{H}^{-}\right)$матерією забороненої зони ядра. Отже, утворення біологічних ядер починається 3 виникнення заборонених зон. Після завершення цього кодованого процесу відбувається народження організму, який переходить на сонячну позитивну $(+)$ вуглецеву $\left(\vec{C}^{+}\right)$матерію, яка знаходиться на вищому Місячному рівні. Це означає, що людина після народження споживає набагато більше сонячної матеpiї, чим у стані немовляти. Якщо зав'язь немовляти відбувається на негативній матерії водню $\left(\vec{H}^{-}\right)$, що поступає через ядро Землі з космосу, то генетичний вектор не пропускає сонячну позитивну вуглецеву $\left(\vec{C}^{+}\right)$матерію до немовляти, а тільки регулює величину потенціалу на головних рівнях ядер мікросвіту, створюючи умови для заповнення забороненої зони ядра.

Тому розглянемо цю форму життя. Зрозуміло, що розвиток немовляти в комплексі з генетичним вектором життя має генетичний код $\Gamma К=642.135$, де $642-$ це ядерний цикл накопичення головного енергетичного рівня ядра і 135 - це критичне наповнення ядерних заборонених зон. Над поверхнею Землі розмістилося шість енергетичних рівнів, на яких і $є$ клітини генетичного вектора, який прийшов із Марса. Порожня марсіанська оболонка виявилася блукаючою над поверхнею Землі в пошуках родинного потенціалу зі свого генетичного вузла. Відшукавши енергетичну зав'язь $(C-H)$, iii захоплює яйцеклітина або інша біологічна клітина, яка попала в енергетичне середовище і намагається 3 нього вийти способом розподілу. Тому розвиток біологічних клітин немовляти починається з утворення заборонених зон їх ядер, а головні рівні клітин взагалі спустошені та перебувають у такому стані до народження. Наповнювана матерія забороненої зони ядра надходить від добового циклу руху матерії на Землі. А оскільки маємо впродовж доби день і ніч, іншими словами - $(+)$ вуглецю $\left(\vec{C}^{+}\right)$i $(-)$водню $\left(\vec{H}^{-}\right)$, то за добу генетичний вектор життя наповнюватиметься на півперіод (рис. 4).

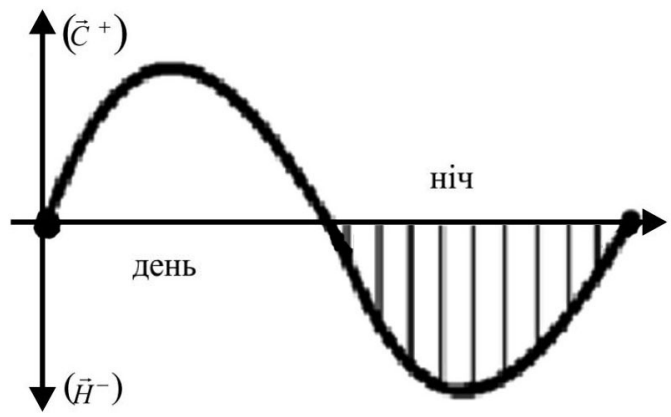

Рис. 4. Добові цикли руху водневої і вуглецевої матерії на Землі

Отже, для накопичення повного одного циклу необхідно два дні. Коли перша критична точка генетичного вектора життя має критичне наповнення забороненої зони ядра - число 135, то тривалість формування цієї фази життя $\left(T_{1}\right)$ визначимо: $T_{1}=135 \times 2=270$ днів, або $270: 30=9$ місяців. Так, ми одержали першу критичну точку формування генетичного вектора людського життя. Період вагітності, а це не що інше, як наукове, емпіричне узагальнення всім відомого і точно спостережуваних численних емпірично незаперечних фактів. Проте ядро в цьому стані може мати життєвий стан 270 днів і якщо не станеться перемикання 3 матерії водню $\left(\vec{H}^{-}\right)$на матерію вуглецю $\left(\vec{C}^{+}\right)$, то зав'язь розірветься і клітина загине. Це шлях матеріалізації галактичної антиречовини образу людини через матеріалізований ембріон до формування людської речовини (немовля) 3 життям у 270 днів.

Місячний рівень оболонки Землі. Земля не може прийняти могутній потік сонячної матерії. Все довкола згорить. Тому вона ставить обмежувач для сонячної матерії, який повністю блокує іiі доступ до Землі (озоновий шар), пропускаючи від неї лише захисну квантову частину і затримуючи ядрову частину. А оскільки Мiсяць знаходиться на спіралі сьомого витка ядра Землі, то частину сонячної матерії заносить безпосередньо в ядро Землі, де вона змінює свою полярність і виходить у вигляді водневої $\left(\vec{H}^{-}\right)$матерії. Цим вона створює умови енергетичного кругообігу для утворення зав'язі ядер біологічних організмів і ядер клітин його мікросвіту. Якщо подивитися на рис. 2, то можна помітити, що Місяць за один оберт у 28 діб подає в ядро Землі півперіодами сонячну матерію вуглецю $\left(\vec{C}^{+}\right)$, яка переполяризовується ядром Землі. Тому кількість енергетичних днів у році скорочується через Місяць від 365 до 300. На нашу думку, не потрібно намагатися шукати вільну 
енергію матерії Сонця на поверхні Землі, оскільки її тут взагалі немає. В енергетичні дні ця енергія з'являється лише на земних рівнях у біологічній клітині генетичного вектора життя і ії появу відчувають клітини мікроорганізмів, їхні ядра.

Доречно зазначити, (див. рис. 2), що людське життя тісно пов'язане природою 3 другим енергетичним (Мiсячним) рівнем оболонки Землі, який $є$ шунтуючим у русі сонячної додатної $(+)$ вуглецевої $\left(\vec{C}^{+}\right)$матерії. Народившись, людина починає жити на генетичному волокні вуглецю $\left(\vec{C}^{+}\right)$від Сонячної матерії, але вже місячними циклами, де в генетичному коді нашого життя $\Gamma К=642.135$ ядро нашого світу вже заповнене на 135 одиниць. Це фаза життя немовляти $\left(T_{1}\right)$, а 642 - фаза нашого життя $\left(T_{2}^{1}\right)$ i $\left(T_{2}^{2}\right)$ порожня. Заборонені зони ядер нашого мікросвіту повністю забиті генетичним волокном біологічної клітини, що розпалася в ядрі нашої Землі. Ми починаємо заповнювати головні енергетичні рівні ядер клітин нашого мікросвіту, але вже Місячними циклами руху матерії, відійшовши від земних коливань. Місячний цикл становить 28 земних діб або 28 земних коливань. Знаючи, що головні рівні мікросвіту в ядрах людини можуть прийняти лише 642 цикли, обчислимо максимальний вік людини. Для цього необхідно обрахувати кількість енергетичних днів в одному земному році в 365 днів. Знаючи, як вказує Біблія, що сьомий енергетичний рівень ядра Землі викинутий назовні, утворивши Місяць і обертається 3 ним в одному напрямку, то неважко зрозуміти, що кожний сьомий день року (недільний) порожній і матерія перебуває у стані спокою. Тому визначимо кількість таких днів: 365:7=52 неенергетичні дні одного року. А оскільки Місяць за один рік робить 365:28=13 обертів навколо Землі синхронно ядру, то рух генетичного волокна сповільнюється ще на 13 діб. Отже, одержимо таке кількість енергетичних днів: 365-52-13=300 енергетичних днів у році. За цей період Місяць робить циклів: 300:28= 10,71 цикл. Щоб виділити з них тільки Сонячні напівперіоди, необхідно це число зменшити вдвічі: 10,71:2 $=5,35$ Місячних циклів чистої Сонячної матерії в році. Отже, максимальна тривалість життя людини на Землі, яка живе в унісоні з природою, не може перевищити: $T_{2}=642: 5,35=120$ років. Про це говорить і Мойсей. Так, у першій книзі Буття у главі 6, вірші 3 подано таку інформацію: "I промовив Господь. Не буде мій Дух перемагатися в людині навіки, - бо блудить вона. Вона тіло, і дні ї̈ будуть сто і двадиять літ" (Bible, 1988, 1989).

Сонячний рівень оболонки Землі. Як встановлено, Сонячний рівень дуже простий і має будову синусоїди 3 півперіодною подачею сонячної матерії на Землю (див. рис. 4). Це $(+)$ вуглецю $\left(\vec{C}^{+}\right)$i $(-)$водню $\left(\vec{H}^{-}\right)$. Отже, для накопичення повного одного циклу необхідно два дні. Це пов'язано з тим, що тропічна зона планети стопорить рух генетичного волокна. Тобто енергія від Сонця йде, але генетичні нитки вуглецю $\left(\vec{C}^{+}\right)$стоять на місці та синтез в ядрах клітин припиняється. А із зупинкою синтезу припиняється ядрове наповнення. Водночас за один рік лише півроку рухається генетичне волокно (матерія), а півроку воно перебуває у стані спокою. Коли рух волокна відбувається, то ці дні вважають енергетичними. Якщо генетичне волокно $є$ у стані спокою, то всі такі дні вважають неенергетичними і ядра біологічних клітин у такі дні не наповнюються.

Отже, земна будова енергетичного механізму руху сонячної матерії 3 енергетичним волокном вуглецю $\left(\vec{C}^{+}\right)$така, що половину річного циклу воно рухається лише в Північній півкулі, а другу половину циклу рух відбувається тільки в Південній півкулі. Зате в тропічній зоні планети присутні обидва півперіоди сонячної матерії з рухом вуглецю $\left(\vec{C}^{+}\right)$(рис. 5$)$.

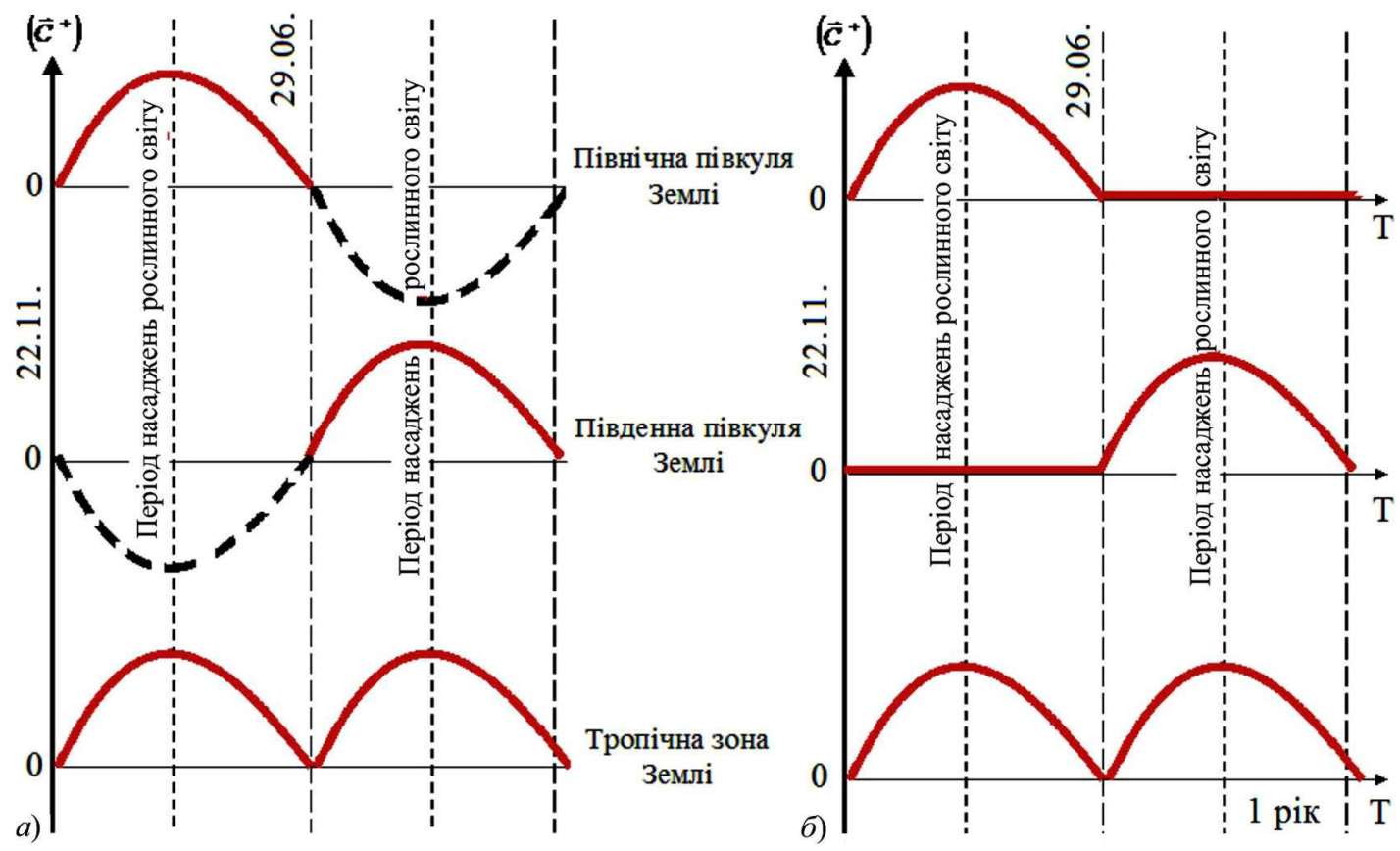

Рис. 5. Рух волокна вуглецю $\left(\vec{C}^{+}\right)$сонячної матерії: а) нічний варіант синусоїди; б) реальний стан руху

Це навіть підтверджує рослинний світ, даючи один урожай за річний цикл у Північній півкулі та зміщений на півперіод один урожай у Південній півкулі. А в тропічній зоні рослинний світ дає два-три урожаїв за со- нячний річний цикл. Отож, витікає, що сонячна матерія, яку на Землю несе сонячний тороїд, складається 3 двох видів генетичних матерій у вигляді ниток. Це - генетична матерія, яка захищає генетичну нитку вуглецю 
$\left(\vec{C}^{+}\right)$. Тому необхідно подати елемент матерії Сонця (рис. 6).

\begin{tabular}{|c|c|c|c|}
\hline 321 & 321 & 321 & $\mathrm{i}$ \\
\hline $\begin{array}{c}\text { I так далі } \\
\text { том вуглецю } \\
\left(\vec{C}^{+}\right)\end{array}$ & $\begin{array}{l}\text { Третій атом } \\
\text { вуглецю }\left(\vec{C}^{+}\right)\end{array}$ & $\begin{array}{l}\text { Другий атом } \\
\text { вуглецю }\left(\vec{C}^{+}\right)\end{array}$ & $\begin{array}{l}\text { Перший атом } \\
\text { вуглецю }\left(\vec{C}^{+}\right)\end{array}$ \\
\hline
\end{tabular}

Рівень оболонки Землі

Рис. 6. Генетична нитка волокна вуглецю $\left(\vec{C}^{+}\right)$сонячної матерії

Як видно з цього рисунку, генетична нитка вуглецю $\left(\vec{C}^{+}\right)$складає основу сонячної матерії, будучи її ядром. Тому генетична нитка волокына вуглецю $\left(\vec{C}^{+}\right)$сонячної матерії, яка утворює ядро сонячної матерії, складається 3 підсумкового числа потенційних точок, розташованих у кодовому порядку вектора вуглецю $\left(\vec{C}^{+}\right)$утворюючи дипольний зв'язок атома вуглецю $\left(\vec{C}^{+}\right)$, а в просторі 3 протилежним обертанням спіралі в'яже атом цієї речовини. А оскільки вона складається із суцільних потенційних циклів атомів вуглецю, які в земних умовах синтезують речовину вуглець $\left(\vec{C}^{+}\right)$, то така його кількість, що йде від Сонця Землі, не потрібна й один з ії рівнів енергетичної спіралі оболонки гальмує рух цієї генетичної нитки, не пропускаючи іiї в атмосферу Землі.

Енергетична генетична нитка сонячної матерії $\epsilon$ захистом іiї ядра від дії на генетичну нитку вуглецю $\left(\vec{C}^{+}\right)$ негативного (-) простору, створюючи навколо вуглецевої нитки спіральне обертання одного напрямку. Цим вона зберігає однорідне середовище для ядра матерії, яким $\epsilon$ волокно вуглецю $\left(\vec{C}^{+}\right)$. А за допомогою гіроскопічних сил задає ядру матерії витягнутий прямолінійний стан. Отже, енергетична нитка не повинна мати зв'язки 3 генетичною ниткою ядра матерії та, в разі зупинки генетичної нитки, вуглецю $\left(\vec{C}^{+}\right)$на земному рівні оболонки, завжди продовжить рух до поверхні Землі. Це дає змогу виписати загальний вид матерії Сонця, знаючи, що в Сонячному матеріальному тороїді окремо створена зона для рівня Землі з кодом 37, де іï біологічні клітини мають ядра зі семи витками ядрової спіралі (рис. 7). 3 цього рисунку бачимо, що позитивний простір для ядра матерії створює оболонка, яку називаємо квантом сонячного світла i, яка має сім витків спіралі, радіус витків відповідає рівням ядрової спіралі нашого мікросвіту.

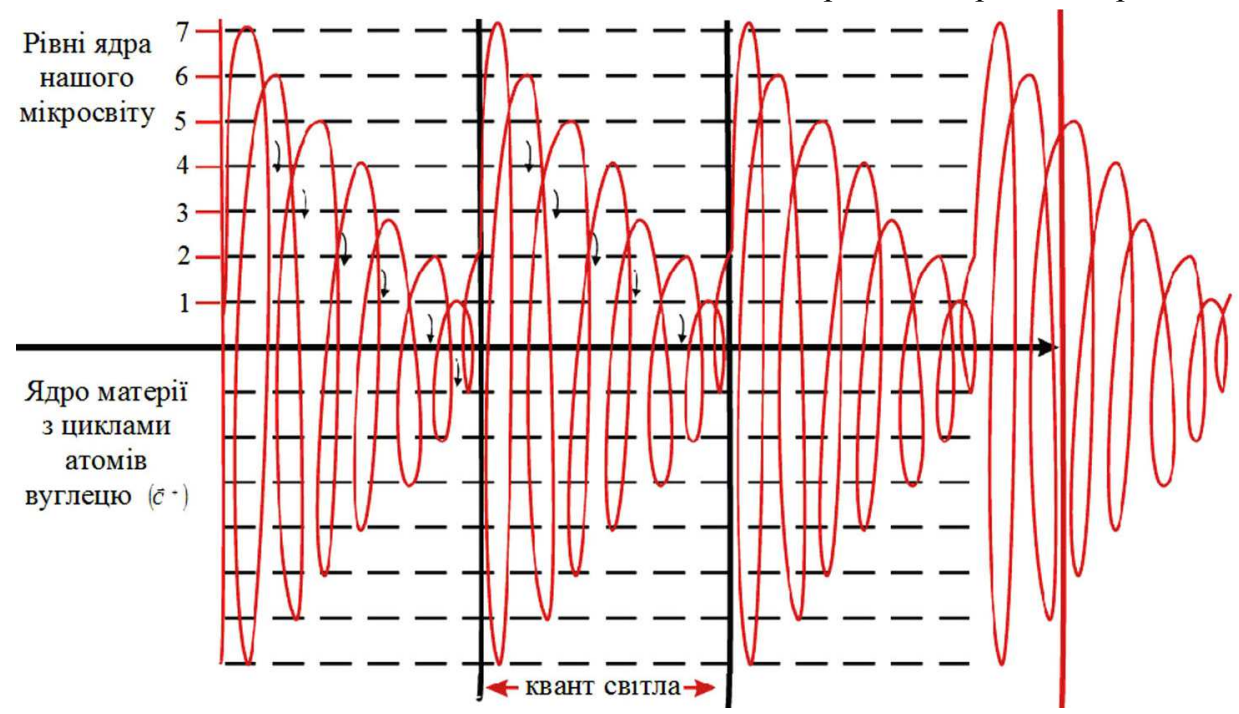

Рис. 7. Будова сонячної вуглецевої $\left(\vec{C}^{+}\right)$матерії, яка рухається від Сонця по сьомому рівні спіралі тороїда

Тому світло має сильний вплив на біологічні клітини рослин (Shlapak, 2008). Але генетичне волокно матеpiï у вигляді іiі квантової оболонки в організм людини постійно подає генетичний вектор біологічного комплексу, наносячи на нього свій код. Цей код заноситься у хребет людини і дешифрується полюсами кодових диполів у вигляді імпульсних подразників. Це і примушує постійно працювати серце людини та інші життєво важливі органи навіть у той момент, коли мозок людини відпочиває або перебуває у відключеному стані. Аналогічно подаємо вид водневої $\left(\vec{H}^{-}\right)$або, як їі ще називають, космічної матерії (рис. 8).

Воднева $\left(\vec{H}^{-}\right)$матерія виникає не в порожньому космосі, а з біологічних клітин організму, що розпадається і який негативне середовище розтягує до такої міри, що утворюється генетичне волокно найпростішого елементу таблиці Менделєєва - водню $\left(\vec{H}^{-}\right)$. Якби в природі існував елемент простіший, то, напевно, ядром цієї матерії був би він. Але ядром цієї космічної матерії є водень - $\left(\vec{H}^{-}\right)$. Тому генетична нитка ядра матерії несе код водню $\left(\vec{H}^{-}\right)$. А енергетична генетична нитка, яка захищає ядро матерії і створює йому прямолінійний напрямок, постійно обертаючись у зворотному напрямку, має три енергетичні рівні, які відповідають рівням оболонок нашого світу, постійно зміцнюючи її стан. Це також помітно за рослинним світом.

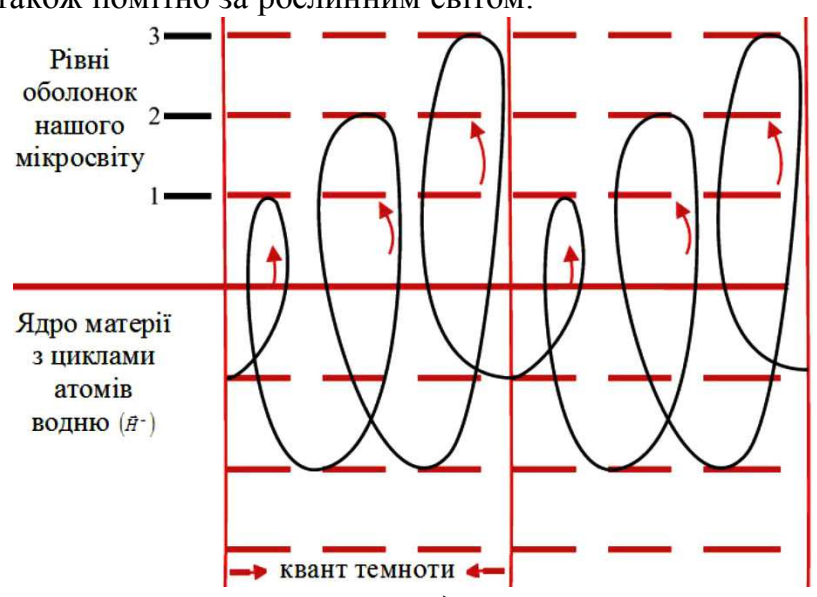

Рис. 8. Будова водневої матерії $\left(\vec{H}^{-}\right)$, яка рухається від матеріального об'єкта, що руйнується, по третьому рівні водневого тороїда 
Удень рослини збільшують свої ядра і виходять 3 енергетичної рівноваги зі своїми захисними оболонками, надаючи рослині млявого стану. А вночі зміцнюються оболонки, повертаючи рослину в енергетичну рівновагу, і під ранок вона набуває бадьорого вигляду, відновленого стану. Цей процес забезпечують кванти денного (Сонячного видимого) та нічного (темного невидимого) світла, оскільки вони мають різні швидкості руху, відповідно 300000 і 700000 км/с (Shlapak, 2009e).

Головні рівні оболонки нашої Землі побудовані 3 матерії водню $\left(\vec{H}^{-}\right)$, які захищає атмосферна оболонка. Якщо рівень атмосферної оболонки знижується, то сонячна матерія вуглецю $\left(\vec{C}^{+}\right)$стикається 3 космічною матерією водню $\left(\vec{H}^{-}\right)$і починаються атмосферні явища (Shlapak, 2011b). У цьому потрібно акцентувати увагу на те, що, якщо знижується концентрація кисню в атмосфері, а концентрація вуглекислого газу нормальна, то ядро матерії Сонця не вступає в синтез і відбуваються звичайні газові явища, які поповнюють планету киснем і водою. Якщо ж концентрація вуглекислого газу зменшується, то сонячна вуглецева $\left(\vec{C}^{+}\right)$матерія в повному об'ємі досягає рівня водневої $\left(\vec{H}^{-}\right)$матерії. Від цього відбуваються ядрові газові розряди, у яких бере участь і ядро Сонячної матерії і вони мають ядровий характер у вигляді кулеподібних блискавок. Якщо такі блискавки виникають, то це означає, що в атмосфері занижена концентрація вуглекислого газу і природа його поповнює

Отже, чітко простежуємо і математично доводимо, що життя людини відбувається на рухах матерії водню $\left(\vec{H}^{-}\right)$і вуглецю $\left(\vec{C}^{+}\right)$. Це наше життя у стані немовляти $\left(T_{1}\right)$ і людини $\left(T_{2}^{1}\right)$ i $\left(T_{2}^{2}\right)$, де задіяні лише два рівні оболонки Землі: Земний і Місячний. Але, як бачимо (див. рис. 2), існує третій рівень - Сонячний. Тому, за аналогією, життя на сонячній вуглецевій $\left(\vec{C}^{+}\right)$матерії, але вже сонячними циклами, є на Землі. Це - третя форма життя людини на Землі. Доречно вказати, що академічній медицині відомо явище народження близнюків. Це дві або більше дитини, які народилися майже одночасно в однієї матері. Близнюки бувають однояйцеві, які розвиваються $з$ однієї заплідненої яйцеклітини, мають однаковий генотип, завжди однієї статі, і різнояйцеві 3 різних яйцеклітин, дозрівши одночасно. Проте варто зазначити, що академічна наука не розглядає взагалі третю форму життя, форму життя послідовних близнюків, оскільки це фізичне явище людині невідоме. Тому й не проводяться фундаментальні дослідження. Проте, взявши Біблію в руки, по-перше, що звертає нашу увагу, це назва, яку подано в алегоричній формі, а в прямому перекладі означає друге народження людини, послідовний близнюк, де слово "ДВІЧІ" замінено словом "БІНОМ". Російською мовою як найбільш вдало перекладено: "БИноминальный БЛИзнец Я", що скорочено означає "БИБЛИЯ". Тому зупинимося на докладнішому роз'ясненні. Так, читаючи Святе Благовіщеня від Іоанна в главі 3 "Розмова Ісуса 3 Никодимом" у вірші 4, звертаємо увагу на їхнє спілкування. Так, Никодим каже йому: "Як може людина родитися, будучи старою? Хiба може вона ввійти до утроби своєї матері знову і родитися?" (Bible, 1988, 1989). Уже з цього вірша зрозуміло, що йдеться про явище, яке дає два життя, тільки послідовно. Втім, не звертаючи уваги на іронічну насмішку авторів Біблії з наших наукових знань, але все ж таки, як наших передвісників уже і в третє тисячоліття нашої ери, необхідно ствердити, що Біблія описує явище життя та народження послідовних близнюків, а це не що інше, як унікальне явище природи. Це третя форма життя людини на Землі 3 тривалістю життя у 1000 років. Це найпотаємніше явище другого народження людини, яке у свідомості суспільства займає належне місце в різних образах. Науковий термін - двічі народжений, біномінальний близнюк я та лімфей. Алегоричний (міфологічний) термін - "Син людський", "Син божий", Христос, людина Велетень, двічі померлі. Доречно акцентувати, що образи "Сина людського" i "Сина Божого" автори Біблії пов'язують 3 процесами поведінки клітини за другого народження людини, де генетичне волокно людини розпадається на речовину й антиречовину ще за іiі життя, що веде до фізіономічної видозміни. Тому розглянемо цей процес на земному житті, та як такий стан (нововидоутворення) можна простежити.

Третя форма життя людини на Землі (послідовних близнюків, двічі народжених, двічі померлих, Сонячної людини, Сина людського та її тривалість, як явище природи - $\left(T_{3}\right)$. Це найпотаємніше явище другого народження людини. Для розкриття суті цього явища передусім необхідно розглянути ядрову клітину. Але перед початком іiі розгляду акцентуємо увагу на дуже важливій речі із життя біологічної клітини (рис. 9). Поперше, "Чому біологічна клітина має код оболонки нульовий?"

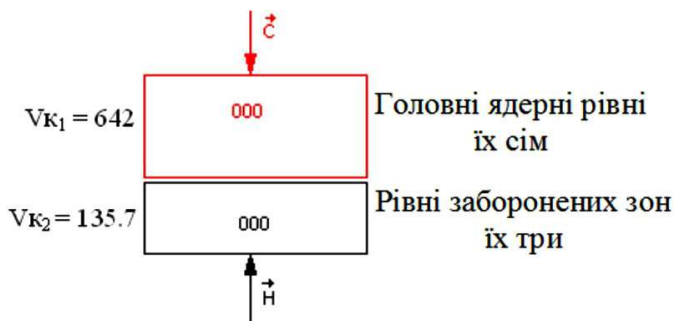

Рис. 9. Порожнє ядро біологічної клітини після виходу захисної оболонки 3 його генетичним волокном

Ядро має кодовий знак наповнення, а оболонку потрібно розглядати завжди окремо. Секрет полягає в тому, що оболонка завжди виконує захисні функції і вона повинна бути відносно ядра дуже агресивною. Однак якщо її рівні заповнить матерія, то агресивність зникне. Так, іiі простір заповнений якоюсь речовиною, необхідною для ядра. Якщо ця речовина зникає, то iі рівні оголяються і за зустрічі з навколишнім середовищем завжди знову синтезується ця речовина, яка витісняє навколишнє середовище і ховає рівні оболонки від зустрічі 3 нею. Тому захисна оболонка завжди знаходиться неначе в атмосферній оболонці ядра. I ця оболонка захищає іiі головні рівні. Якщо рівні розкриваються, то оболонка поповнює це атмосферне середовище. По-друге, "Що означає порожня ядрова клітина або порожнє ядро?" Дивлячись на його будову, здавалося б ці ядра не мають шансу на життя, адже ядра 3 порожніми головними рівнями, як зображено на рис. 9, здатні залежно від зовнішнього середовища виносити їх назовні, змінюючи фізичні властивості. Так, відбувається за кристалізації або плавлення води, за випаровування або конденсації. Отже, у ядер виникли умови для винесення голов- 
ного енергетичного рівня сонячної частини назовні та створити спіраль нової оболонки клітини. Вектор життя людини, який пішов, знаходиться на шостому енергетичному рівні зовнішньої оболонки Землі, а на сьомому рівні утримується біологічна клітина людини. Отже, ядрова спіраль, виносячи шість своїх витків назовні, може бути захоплена спіраллю планети і злитися 3 нею, замінивши генетичний вектор, що пішов, і перенести життя людини на верхній сонячний рівень планети. А перехід життя системи на верхній рівень називають народженням. Отже, система може мати друге народження на Землі. I це можуть виконати головні енергетичні рівні ядра. Якщо сонячні рівні підуть з ядра, то в ядрі залишаться лише три рівні водневої матерії $\left(\vec{H}^{+}\right)$і біологічна клітина набуде стану антиречовини, у якої холодне ядро і гаряча оболонка. Температура тіла такої людини знизиться і буде визначатися температурою навколишнього (оточуючого) середовища. А цикл сонячної матерії буде дорівнювати 1 року: 1 цикл = 1 року. Винесення рівнів сонячної матерії за межі ядра залишить його у стані одних заборонених рівнів водневої матерії $\left(\vec{H}^{+}\right)$. Але і ці рівні деформовані сторонньою (негативною) клітиною і набули деформації від 135 до 135.7. Запишемо це у вигляді: $135+0.7=135.7$, а оскільки 7 клітина формується на Землі, то вираз матеме такий вигляд: 135.7. 3 цього виразу обчислимо код ядра нової клітини. Новий ядровий код клітини буде перебудовуватись під час його другого народження і він буде залежати від місцезнаходження людини. Оскільки клітина знаходиться на сьомому витку спіралі, де вимірювання ведеться в семизначній системі відліку, то число 0.7 відповідає одній цілій одиниці. Тому до числа 135 потрібно додати одну кодову одиницю. Це було б правильно, якби така біологічна клітина знаходилася б на верхньому рівні спіралі, де 1 цикл відповідає 1 року. Але ця клітина знаходиться в кінці спіралі, де 1 циклу вже відповідає 365 добам. Тому до нового числа 135 необхідно додати кодову одиницю, що виражається числом 365 i новий код об'єму ядра $(V \kappa)$ цієї біологічної клітини одержить кодовий розмір: $V \kappa=135+365=500$. Цифру 500 нам уже відомо. Це пов'язано з діаграмою Сонячної системи, де цифра 500 відповідає Ною, а Ной - це Сонце (Bible, 1988; Shlapak, 2009a). Відразу бачимо, що такий об'єм є половиною якоїсь цілої частини. Спробуємо 3 цим розібратися. Планета Земля має гаряче ядро 3 сімома енергетичними рівнями і трьома головними рівнями холодної оболонки (рис. 10). 3 рис. 10 бачимо, що спіраль ядра клітки людини розміщується в заборонених зонах земної оболонки і не може торкатися ії головних рівнів, а заходить в тороїд сонячній матерії Венери.

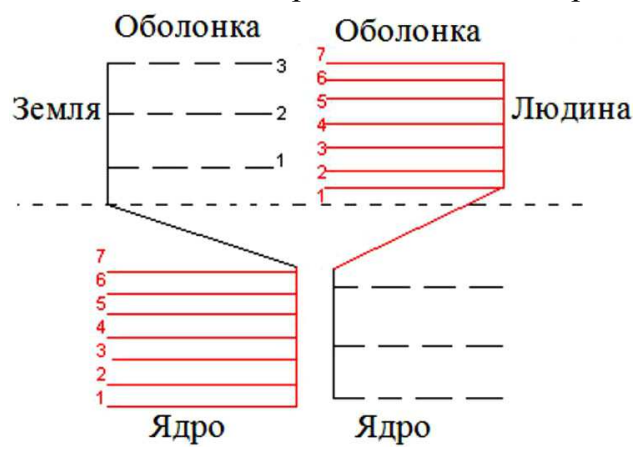

Рис. 10. Друге народження людини приводить до появи на Землі її антиклітини
Енергетична густина матерії цього тороїда визначається кодовим положенням Венери в Сонячній системі 2, помноженому на кількість десяткових переходів, як зазначає Піфагор (Vocabulary, 1989), від Плутона, а їх вісім. Тому спіраль життя цієї людини з антиклітиною Землі починається 3 тороїда Венери 3 енергією $W=2 \cdot 10^{8}$ космічних одиниць. За одиницю космічної енергії беруть умовно енергію відкритого космосу за межами Сонячної системи. Тоді на рівні Плутона вона посилюється у 10 разів. Її основа збільшується у 10 разів і т.д. Венера збільшує вже в $10^{8}$ разів. А енергія Сонця $W c=10^{10}$ космічних одиниць. Але, з огляду на відсутність у Сонячній системі антиклітин планет, оскільки їх виніс генетичний комплекс навіть із Галактичного світу, а енергетичного компенсатора для планет Сонячної системи Галактика не має, то густина енергії планет ще збільшується в кодовому розмірі положення планети від Сонця. I наша Земля занурена в Сонячну матерію 3 енергетичною густиною $W_{\text {землі }}=3 \cdot 10^{7}$ космічних одиниць. Отже, в природі кожна планета 3 клітиною своєї біологічної істоти вищого порядку, через його друге народження, може створити свою антиклітину і вступити 3 нею в енергетичний диполь (рис. 11).

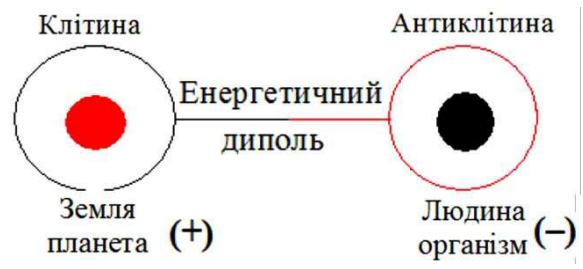

Рис. 11. Утворення планетного диполя в Сонячній системі між людиною і планетою із єдиною захисною оболонкою

Тому якщо обрахуємо об'єм генетичного ядра нової біологічної клітини, яку вона утворює за другого народження людини $V_{\kappa}=135+365=500$, то через енергетичний диполь кодовий об'єм ядра Землі також стає: $V \kappa_{\text {зем- }}$ $m=500$. Потрібно встановити відмінність між ядрами Землі та людини в цьому енергетичному диполі. Так, головну відмінність між полюсами планетного диполя "Людина - Земля" можна звести до такого: Ядро планети Земля звільняється від матерії, а ядро тваринного світу, зокрема й людини, заповнюється цією матерією. Період заповнення ядра людини матерією Сонця залежить від кількості земних циклів планети Земля в Сонячній системі. Земля ж, знаходячись у Сонячній Системі, також як Сонце, підкоряється не Земним, а Сонячним і Галактичним циклам. I період повного спустошення ядра Землі легко визначити, знаючи їі кодовий об'єм, який дорівнює 500.

Коли біологічна спіраль життя планети Земля відбувається ЗА його головними енергетичними рівнями, то спіраль життя людини розташована в заборонених зонах цих рівнів і обидві ці спіралі створюють єдиний біологічний комплекс. Створюючи таку людину, відмерла клітина Землі неначе прагне ожити, створюючи в собі, в його обличчі прообраз своєї антиклітини галактичного світу. Але така людина не може повною мірою виконувати функцію земної антиклітини, оскільки вона створена $з$ матерії Сонця. Це Сонячна людина, яка потрібна лише Землі, а після смерті її мікросвіт ядра не розпадається і ніколи його клітина не зникне. На нашу думку, такий стан можна побачити у монахів із Ближ- 
ніх і Дальніх печер Києво-Печерської лаври. Біблія в "Діях Святих Апостолів", глава 2, вірш 31 про це явище природи говорить так: "Він раніше сказав про воскресіння Христа, щуо не залишена Його душа в пеклі, $i$ плоть його не бачила тління".

Отже, якщо прообраз антиклітини Землі дійсно в природі може існувати, то життя "Сонячної людини", без сумніву, укаже на те, що Сонце перебуває також у стані антиклітини і воно має гарячу оболонку і холодне ядро. Тут доречно акцентувати, що в науці немає єдиної думки щодо температури ядра Землі. Вчені вказують, що температура ядра Землі $5000{ }^{\circ} \mathrm{C}$ (Sukhonos, 2002). Однак є думка про $300{ }^{\circ} \mathrm{C}$, та про холодне ядро і навіть пустотілість. Отож, можна ствердити, що генетичний код 642.135 у біологічної зав'язі $(C-H)$ мікросвіту людини, з розворотом спіралі, переходить із стану накопичення у стан розпаду.

Генетичні набори водневої $\left(\vec{H}^{-}\right)$і вуглецевої $\left(\vec{C}^{+}\right)$ матерії за цього відносять порожні біологічні клітини небесної і земної частини біологічного комплексу життя. Біологічна система, яку покинув біологічний комплекс великого і малого кругообігу, природі не потрібна i тіло такої системи навіть після смерті з часом не розкладається. Отже, від розриву зав'язі $(C-H)$ залишається порожня зав'язь сотих із водневою $\left(\vec{H}^{-}\right)$ємністю матерії, оскільки для эї руйнування необхідні великі напруги і саме ця затримка, дає змогу рослинному світу створити нову зав'язь $(H-\Gamma)$, де Г - гібрид. Це гібридна зав'язь 3 річним об'ємом життя в 365 днів. Ось де суть процесу фізіономічної зміни на видовому рівні. У цьому необхідно акцентувати увагу на підстави, які висвітлені на рівні гігаеволюції (Shlapak, 2010d), де доведено, що тваринний і рослинний світи мають прямі зв'язки, які виражаються у видозміні матерії: тварина $\rightarrow$ (видозміна матерії через Сонячну систему) $\rightarrow$ рослина $\rightarrow$ (зворотна видозміна матерії через Сонячну систему) $\rightarrow$ тварина $\rightarrow$ (видозміна матерії через Сонячну систему) $\rightarrow$ рослина... і так нескінченно.

Тому код людини-гібрида становить: ГК=135.365. Коли у звичайної людини циклічний об'єм ядер мікросвіту (Vo) становить: $V o=642+135=777$ циклів, то у "Coнячної людини-гібрида" циклічний об'єм ядер мікросвіту $(V c)$ складе: $V c=135+365=500$ циклів, де видимий розмір ядер мікросвіту людини зменшився на 277 циклів, що приводить до фізіономічної видозміни. Про це акцентується у главі 4, вірші 8 Плачу Ієремії: "A mеnер темніше всього чорного лиия їх; не взнають їх на вулииях; шкіра їх прилипнула до кісток їх, стала сухою, як дерево" та у главі 3, вірші 16: "Скрушив каменями зуби мої, покрив мене попілом". Це викликає сильну зміну м'язової тканини, шкіри і зубів людини, яка переходить у третю форму життя людини на Землі. Маючи цю інформацію і знаючи, що зав'язь рослинного світу відбувається на земному рівні нижнього термосного шару планети, а наповнення йде з його верхнього, Сонячного рівня, де за один рік виникає лише 0,5 циклу, ми без зусиль обчислимо період життя Сонячної людини: $T_{3}=V c$ : $\Pi c=500: 0,5=1000$ років, де: $V c-$ циклічний об'єм ядер мікросвіту; Пс- кількість виникаючих циклів за один рік. Це астральне безсмертя. Откровеніє Івана Богослова глава 20, вірш 4: "... Вони ожили і царювали з Христом тисячу років". Тому, без сумніву можна подати повну діаграму переходів біологічної клітин людини на
Землі за енергетичними рівнями оболонки Землі (рис. 12).

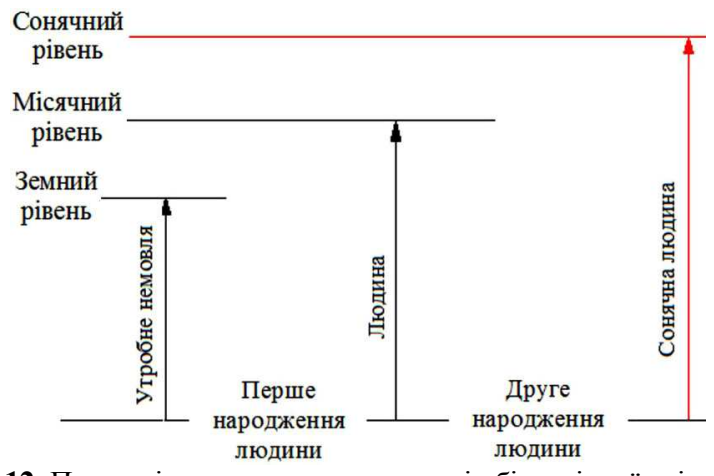

Рис. 12. Повна діаграма земних переходів біологічної клітин людини на Землі

Отже, третя форма життя людини на Землі, як явище природи, має свій простір, а отже, є механізм запуску процесу проходження і переведення людини 3 другої форми життя із 120-річним віком у третю - із 1000-літнім життям. Це явище послідовних близнюків, і воно існує в природі. Так само, як відомий людині механізм зародження немовляти в утробі матері впродовж дев'яти місяців (перша форма життя людини на Землі) та перехід немовляти в другу форму життя людини на Землі з 120-річним віком, що, без сумніву, є всім відомим і беззаперечним фактом.

3 наукового погляду, як зазначено у главі 1, вірші 12 Соборного Послання Святого Апостола Іуди, йдеться про розрив біологічної зав'язі $(C-H)$ людини ще за їі життя. Зазначено, що у природі існує механізм роз'єднання речовини й антиречовини або клітини й антиклітини. Водночас антиречовина як космічна, вічна у визначений термін, для Землі 120 років, покидає земний енергетичний рівень. А речовина, клітина в процесі перебудови залишається живою, але вже нетлінною. I це пов'язано із зміною лише об'єму ядер мікросвіту людини ще за іiі життя. Саме така зміна, перебудова, яка пов'язана з розривом біологічної зав'язі $(C-H)$, забезпечує подальше життя людині у третій формі життя. Без перебудови об'єму ядер свого мікросвіту, за розриву зав'язі $(C-H)$ людина відразу б загинула. Перебудова об'єму ядер мікросвіту людини завершується лише фізіономічною видозміною, появою людини-гібрида. Це гібрид рослинного і тваринного світу, оскільки їхні світи є взаємопов'язані. Це явище природи викликає сильну зміну м'язової тканини, шкіри і зубів людини, яка переходить у третю форму життя людини на Землі. Але саме це фізіономічне видоутворення людини забезпечується астральним безсмертям. Тому цікавим є запитання: "А чи є таке явище на Землі?". С. Це стан монахів дальніх і ближніх печер Києво-Печерської лаври, мумій, склад яких нещодавно знайшов у пісках доктор Ш. Лиман у Єгипті, та болотних мумій Англії, Німеччини та інших країн (Tila, 2018). 3 фізичного погляду, явище нетлінності тіла людини пов'язане лише 3 роз'єднанням за життя біологічної зав'язі $(C-H)$. Ось чому Іоанн Богослов вказує, що люди-гібриди будуть священиками Бога і Христа, і будуть царювати з ними тисячу років. Але в цьому виникає запитання: "А навіщо людині життя гібрида та ще й впродовж 1000 років?" Відповідь знаходимо у Святому Благовіщені від Іоанна у главі 21, вірші 25, де зазначено: "Багато, щзо і інше створив Ісус; але, якби писати про те детально, то, 
думаю, і самому світу не вмістити б написаних книг". Ось де ключ до розгадки таємниць пірамід Сгипту і їхніх мумій, мумій, знайдених у болотах і пісках, яким понад 2000 років і які є нетлінними, пустелі Наска, календарів народу Майя і особливо юліанського, і григоріанського календарів, які $є$ системою рахунку днів, якою впродовж 2500 років користується весь світ. Це є і центури доктора Нострадамуса. Тому, без сумніву, можна вказати, що авторами таких знань 3 таємниць природи на Землі є люди, які були переведені в третю форму життя людини на Землі, тобто жили сонячними циклами руху матерії, а не місячними, як живе звичайна людина. Також варто зазначити, що людина у третій формі життя вільно може розмовляти будь-якою мовою, яка існувала та існує на Землі. Про це говорить Біблія. Це ключ до розшифрування всіх таємниць зі Стародавнього письма доісторичних цивілізацій.

Однак людина в третій формі життя, як гібрид - безплідна. Так, у посланні Святого Свангелії Від Луки у главі 20, вірш 34 Ісус сказав їм у відповідь: "Женяться й заміж виходять сини изього віку", а у вірші 35 сказано: "А ті, щуо будуть достойні того віку й воскресіння з мертвих, - не будуть ні женитись, ні заміж виходити". У вірші 36 читаємо: "Ні вмерти вже не можуть, бо рівні вони Ангелам, і вони сини Божі, синами воскресіння бувши". Доречно ще раз звернути увагу на висловлювання Іуди у главі 1 Соборного Послання Святого Апостола Іуди, де у вірші 12, він дає пояснення, узагальнивши інформацію 3 другого народження, вказуючи, що людина зі 1000-літнім життям: "Це безводні хмари, носимі вітром; осінні дерева, безплідні, двічі померлі, викоренені". Сьогодні - це іконні зображення святої трійці: "Отець, син і святий дух". Святий дух це людина, яка більше ніж 2000 років тому жила в третій формі життя зі 1000-літнім життям сонячними циклами і була знищена людьми із "Закону" за реформаторське втручання у структуру будови суспільства.

Доречно також акцентувати, що автори Біблії покладають відповідальність за переведення земної людини в третю форму життя на Землі на людей із "Закону". Свангелія від святого Луки, глава 11, вірш 52: "Горе Вам, законникам, бо взяли Ви ключа розуміння, самі не ввійшли, і тим, хто хотів увіитти, боронили!"

\section{Висновки:}

1. Розглядаючи еволюцію (історію) розвитку органічного світу Землі, ми дійшли висновку, що основною теоретичною помилкою іiі $€$ те, що вона ще з часів Дарвіна прив'язана до Землі. На Землі, на видовому рівні як тваринного, так і рослинного світів еволюція не простежується.

2. Для розкриття суті еволюції людини і рослини необхідно ув'язати історію розвитку органічного світу Землі 3 Галактичним кругообігом органічної речовини, де Сонячна система $є$ лише механізмом, через який проходить галактична матерія від гігантського померлого біологічного організму, який проживав на поверхні Галактики, а після смерті, розімкнувши свій простір, випустив весь свій мікросвіт. У задачу Сонячної системи входить збирання і вдосконалення цієї матерії за своімм планетами на шляху до Сонця, де вдосконалена матерія отримає незалежність і зможе самостійно жити як незалежна клітина поза межами Сонячної системи. Однак водночас сформована клітина галактичної матерії Сонцем буде відправлена на поверхню Галактики в іiі рослинний світ.
3. Еволюція (історія) розвитку органічного світу Землі, як за Дарвіном, чітко простежується за планетами Сонячної системи, де дійсно на видовому рівні життя людини формується з планети Плутон в напрямку до Сонця. Так, на Плутоні клітина людини має ядро з одним органом і дев'ятьма захисними оболонками, на Землі ядро має сім органів із трьома захисними оболонками, тоді як на Меркурію ядро повинно мати дев'ять органів і одну захисну оболонку.

4. Закон збереження матерії на Землі не діє. Наприклад, згоріли дрова, зіржавіло залізо, де все поділося. Ще Михайло Ломоносов дав своє формулювання закону збереження маси речовини такими словами: "всі зміни, що трапляються в натурі, такого суть стану, що скільки чого в одного тіла відніметься, стільки додається до іншого, так, якщо де трохи зменшиться матерії, то збільшиться в іншому місці". Вчені до сьогодні не можуть знайти цього іншого місця. У природі відбувається усе набагато простіше. Весь органічний і неорганічний світ має свій генетичний код. Наприклад, генетичний код людини $8^{1}-642.135-6^{1}$. Що це значить, $6^{1}-$ коли на планеті Марс завершилося життя людиноподібної істоти, то воно синтезувалося і виникло на планеті Земля 3 кодом $7^{1}$, а коли життя людини завершиться на Землі, то матерія переміститься на планету Венеру з кодом $8^{1}$. Маючи потенційні точки життя на Землі, матерія в точності відтворить життя неорганічного об'єкта чи біологічного організму на Венері. Ось як у природі діє закон збереження матерії. Тут питання може бути лише в якій зоні планети і на якому їі рівні виникне біологічне життя.

5. На Землі існують три рівні ядрового наповнення: Земний, Місячний і Сонячний, які дають можливість природі формувати три форми життя людини на Землі, коли людина може жити як на водневій космічній матерії, так і на вуглецевій сонячній матерії.

6. Плід є першою формою життя людини на Землі з терміном життя в 270 діб або 9 місяців $\left(T_{1}\right)$. Немовля живе і розвивається земними циклами руху водневої космічної матерії, яка впродовж 9 місяців поступає на земну поверхню з ядра Землі.

7. Народившись, через мікросмерть, немовля переходить у другу форму життя уже людини на Землі з природним терміном життя у 120 років $\left(T_{2}\right)$. Народившись, людина переходить жити на вуглецеву сонячну матерію, яка поступає на земну поверхню місячними циклами руху матерії.

8. У другій формі життя людини на Землі народжуються люди у двох формах. Це люди із "Віри" $\left(T_{2}^{1}\right)$ і люди із "Закону" $\left(T_{2}^{2}\right)$. У людей із "Закону" зірвана захисна оболонка, яка не видима для людей із "Віри", а тому фізіономічно-видимої різниці між ними немає, однак вони різняться за способом життя.

9. Людина із "Закону" живе завдяки енергетичній силі людини із "Віри", чим може скорочувати ії вік аж до половини 3 відведених природою 120 років, але переважно забирається 40-50 років, однак це потребує додаткових досліджень.

10. Розкрито суть народження послідовних близнюків. Це третя форма життя людини на Землі впродовж 1000 років $\left(T_{3}\right)$. Це найпотаємніше явище природи, яке академічній науці невідоме, коли людина живе на вуглецевій матерії, але вже не місячними, а сонячними циклами.

11. У притчі розмови Ісуса з Никодимом останній каже йому: "Як може людина родитися, будучи старою? Xiба може вона ввійти до утроби своєї матері знову і ро- 
дитися?", тобто йдеться не про друге послідовне народження людини в утробі матері, а про зміну об'єму мікроядер людини з об'єму 500 одиниць за життя у 120 років до 277 за життя у 1000 років, яка забезпечується розривом біологічної зав'язі $C-H$ ще за життя людини, коли астральний об'єм ядер (зав'язь $H$ ) покидає земний рівень, а земний (зав'язь $C$ ) залишається на земному рівні. Людина 3 об'ємом мікроядер у 277 одиниць видозмінюється, але залишається людиною i живе 1000 років. Як сказав Святий Апостол Іуда, "Це безводні хмари, носимі вітром; осінні дерева безплідні, двічі померлі викоренені".

12. Інтелектуальний рівень людини, яка житиме в третій формі життя, сонячними циклами, подано в Біблії: "Багато, що і інше створив Ісус; але, якби писати про те детально, то, думаю, і самому світу не вмістити 6 написаних книг".

13. У старому заповіті Біблії подано механізм запуску людини у третю форму життя, а в новому заповіті описано сам процес переходу та його фізичні та фізіономічні властивості. А також наведено механізм, як ритуалом умертвити людину, в якої запущений механізм переходу в третю форму життя.

14. У Біблії вжито "Син божий" і "Син людський". Складається враження, що це синоніми. Однак, на нашу думку, потрібно розуміти, що Біблія надає простір життя на Землі як "Сину божому", так і "Сину людському", вказуючи, що за наділеними властивостями та інтелектуальним рівнем вони ідентичні, цим самим дає дозвіл на створення третьої форми життя людини з другої, у якої не розірване єднання з природою.

15. Фрігійський бог Атіс, індійський бог Кришна, грецький бог Діоніс, перський бог Мітра і християнський бог Ісус Христос - це нині алегоричні образи, а в реальності люди, які були за допомогою механізму другого народження переведені на 1000-літнє життя людини на Землі. Саме ці люди, "Земні боги" і "Месії", можуть як знищувати, так і започатковувати та розвивати наймогутніші цивілізації.

16. Настав час, коли вивести землян з екологічних, економічних і суспільних катастроф може людина, яка житиме сонячними циклами в третій формі життя. Для цього потрібно відкрити наукову тему, контролювати і фінансувати наукові дослідження.

17. Людина, яка, використавши механізм переходу в третю форму життя на Землі впродовж 1000 років, природно наділена властивістю "Месії" (фрігійський бог Атіс, індійський бог Кришна, грецький бог Діоніс, перський бог Мітра і християнський бог Ісус Христос). Водночас необхідно вказати, що наступний "Месія" повинен стати не реформатором будови суспільства, а провідником людства 3 одного тисячоліття в наступне тисячоліття.

\section{Перелік використаних джерел}

Beili, Dzhill, \& Seddon, Toni. (1998). Doistoricheskii mir. Moscow: Rosmen, 160 p. [In Russian].

Bible. (1988). Iubileinoe izdanie 1000-letie kreshheniia Rusi. Stokgolm: Publishing house B. Getce, 889, 288 p. [In Russian].

Bible. (1989). Vsesoiuznyi sovet evangelskikh khristian-baptistov. Moscow: The Science, 959, 296 p. [In Russian].

Darvin, Charlz. (1991). Proiskhozhdenie vidov putem estestvennogo otbora, ili sokhranenie blagopriiatnykh ras v borbe za zhizn. SanktPeterburg: The Science, 539 p. [In Russian].

Komrat, E. P. (2008). Put k istene: Tainy Vselennoi i chelovecheskogo soznaniia. Donetck: OOO PKF "BAO", 224 p. [In Russian].

Korniienko, N. Ye. (1999). Problemy evoliutsiinoho zhyttia u svitli naukovykh faktiv ta lohiky. Uman: UDPU, 85 p. [In Ukrainian].
Kurliandskii, V. V. (2001). Tainy zhretcov. Moscow: Ripom klasik, 704 p. [In Russian].

Lazarev, A. S. (2003). Rozshifrovannaia Bible ili rekviem tcivilizatcii. Kyiv: A.S.K. "Poligrafkniga", 1064 p. [In Russian].

Lindblad, Ian. (1991). Chelovek - ty, ia i pervozdannyi. Moscow: Progress, 218 p. [In Russian].

Shevchenko, A. Y. (2007). KHrystos. Kyiv: YPYY NANU y MONU "Nauka i osvita", 268 p. [In Ukrainian].

Shlapak, V. P. (2008). Relihiia. CHarlz Darvin. Bible: teorii evoliutsii (istoriia rozvytku) orhanichnoho svitu Zemli: peremoha chy porazka akademichnoi nauky?. Science. Religion. Suspension, 3, 134149. [In Ukrainian].

Shlapak, V. P. (2009a). Alehorychna nauka yak vershyna henialnosti Velykoho i Sviatoho proroka Moiseia. Science. Religion. Suspension, 1, 123-133. [In Ukrainian].

Shlapak, V. P. (2009b). Kovcheh Noia: Rukh materii u Soniachnii systemi ta na yadernykh rivniakh Zemli. Science. Religion. Suspension, 4, 174-178. [In Ukrainian].

Shlapak, V. P. (2009c). Darvin. Vernadskyi: Tochky zoru rizni, a istyna odna. Scientific Bulletin of UNFU, 19(12), 330-332. [In Ukrainian].

Shlapak, V. P. (2009d). CHy vyznachytsia liudstvo iz vchenniam i mistsem CHarlza Darvina i koly? Rol nauky, relihii ta suspilstva $u$ formuvanni moralnoi osobystosti: Materialy KHKHVI Mizhnarodnoi naukovo-praktychnoi konferentsii, (pp. 431-434). Donetsk: IPShI "Nauka i osvita". [In Ukrainian].

Shlapak, V. P. (2009e). Denne ta nichne svitlo v konteksti nauky i relihii. Proceedings of the Forestry Academy of Sciences of Ukraine: Collection of Research Papers, 7, 21-26. [In Ukrainian].

Shlapak, V. P. (2010). Makroevoliutsiia yak osnova pervisnoho zarodzhennia zhyttia i zhyvoho na yadernykh rivniakh Zemli. Scientific Bulletin of UNFU, 20(8), 302-317. [In Ukrainian].

Shlapak, V. P. (2010a). Rukh antyrechovyny yak osnova mehaevoliutsii (istorii) rozvytku orhanichnoho svitu v Soniachnii systemi. Scientific Bulletin of UNFU, 20(4), 294-310. [In Ukrainian].

Shlapak, V. P. (2010b). Nauka i relihiia: fizyka zhyttia na Zemli. Scientific Bulletin of UNFU, 20(1), 315-325. [In Ukrainian].

Shlapak, V. P. (2010c). Mikroevoliutsiia yak osnova zhyttia i vsoho zhyvoho na Zemli. Scientific Bulletin of UNFU, 20(10), 302-317. [In Ukrainian].

Shlapak, V. P. (2010d). Hihaevoliutsiia yak osnova evoliutsii (istorii) rozvytku orhanichnoho svitu na halaktychnomu rivni. Science. Religion. Suspension, 2, 149-163. [In Ukrainian].

Shlapak, V. P. (2011a). Try formy zhyttia liudyny na Zemli yak yavyshche pryrody. Scientific Bulletin of UNFU, 21(3), 345-355. [In Ukrainian].

Shlapak, V. P. (2011b). Vidkryti pytannia u vynyknenni hrozy ta yii naslidkiv. Proceedings of the Forestry Academy of Sciences of Ukraine: Collection of Research Papers, 9, 215-220. [In Ukrainian].

Shlapak, V. P., \& Shlapak, V. V. (2010). Horinnia yak protses vydalennia henetychnoho kodu $\mathrm{z}$ orhanichnoho i neorhanichnoho svitu. Proceedings of the Forestry Academy of Sciences of Ukraine: Collection of Research Papers, 8, 175-181. [In Ukrainian].

Sukhonos, S. I. (2002). Masshtabnaia garmoniia Vselennoi. Moscow: Akademiia Trinitarizma, 312 p. [In Russian].

Systema. (2018). Formuvannia ta evoliutsiia Soniachnoi systemy. Retrieved from: https:/uk.wikipedia.org/Формування та еволюція Сонячної системи. [In Ukrainian].

Tila. (2018). Netlinni tila. Retrieved from: https://m.online.ua/news/ 721280/Нетлінні тіла. [In Russian].

Vernadskyi, V. I. (2005). Vybrani pratsi. Kyiv: Nauk. dumka, 300 p. [In Ukrainian].

Vocabulary. (1980). Mify narodov mira: Terminologicheskii slovar. (Tokarev, S. A. Scientific Ed.). Moscow: Sovetskaia Entciklopediia, (Vol. 1. A-K, 672 p., (1982). Vol. 2. K-Ia). 720 p. [In Russian].

Vocabulary. (1989). Sovetskii entciklopedicheskii slovar: Terminologicheskii slovar. (Prokhorov, A. M. Scientific Ed.). (4th ed.). Moscow: Sovet. Entciklopediia, (In 2 vol., Vol. 2). 1632 p. [In Russian].

Vremia. (2018). Dukh vremeni (film). Retrieved from: https://ru. wikipedia.org/wiki/Дух времени (фильм). [In Russian]. 
Zherar, Enkoss (Papius). (2004). Kabbala, ili Nauka o boge, Vselennoi i Cheloveke: Novoe sovremennoe izdanie, ispravlennoe i dopolnennoe. (Dikson Olard Scientific Ed.). (Troianovskii, A. V. Trans. from France). Moscow: RIPOL klassik: LADA, 448 p. [In Russian].
Zhizn. (2018). Ozhidaemaia prodolzhitelnost zhizni. Retrieved from: https://ru.wikipedia.org/wiki/Ожидаемая продолжительность ж изни. [In Russian].

В. П. Шлапак
Умань, Украина

\section{ЖИЗНЬ ЧЕЛОВЕКА НА ЗЕМЛЕ В КОНТЕКСТЕ ДВИЖЕНИЯ МАТЕРИИ И ЗАКОНОВ ФИЗИКИ}

Автором с точки зрения движения материи и физических законов в своих работах, на основе материализации антивещества в вещество, раскрыт галактический круговорот органического вещества, в том числе в Солнечной клетке (Солнечной системе), в которых автор указывает, что жизнь животного мира есть на всех планетах на различных их уровнях и в различных формах, так как основой жизни животного мира является усовершенствование биологической клетки высшего света, попавшего в Солнечную систему и двигаясь по ее планетам, формируется и совершенствуется для последующей самостоятельной жизни. В данной работе раскрываются процессы формирования и движения органического мира на уровне Солнечной системы, одновременно указывая, что эволюция (история развития) Земли является не одинокой во Вселенной, а тесно связана с галактическим и солнечным круговоротом органического вещества. Обобщены и дополнены исследования по эволюции (истории) развития человека на Земле. Проведено исследование прикладной науки Древнего мира, зашифрованной в Библии, которая дает возможность раскрыть физическое явление последовательных близнецов, которое академической науке неизвестно и суть которого не раскрыта. Жизнь органического мира Земли связывается с основанием движения космической водородной и солнечной углеродной материи, как явлений природы. Дан ответ о работе этих материй и объяснено, зачем они органическому миру на примере Земли. Указано, что водородная материя, меняя свою полярность, через животный мир, двигаясь из космоса по планетам Солнечной системы, которые наделены разной энергетической плотностью, меняя свою полярность, движется на Солнце, поставляя ему водород в качестве топлива для последующего синтеза и его жизнедеятельности. Углеродная материя как продукт процесса синтеза на Солнце, выносится квантами света и рассеивается по планетам своей системы, образуя растительный мир. Отмечено, что животный мир стоит на входе материи в Солнечную систему, а растительный мир - на ее выходе. Определены три формы жизни человека на Земле и ее физиономические видоизменения в зависимости от уровней ядрового наполнения: Земного, Лунного и Солнечного. По расчетам движения материи в Солнечной системе доказано, что энергетически человек живет на водородной и углеродной материях, где доминантной в младенческом возрасте за 9 месяцев является водородная космическая материя, двигаясь по планетам Солнечной системы поступает на земную поверхность из ядра Земли. На этой материи живет и развивается плод, новорожденный в утробе матери в течение 270 суток. Родившись, ребенок, как сформирован человек, переходит жить в течение 120 лет на углеродную солнечную материю, которая поступает на земную поверхность месячными циклами движения материи. Впервые раскрыта суть третьей формы жизни человека на Земле, когда человек из 120-летного возраста, через ритуалы и литургические сны, переходит жить в течение 1000 лет на углеродную солнечную материю, но уже не месячными, а солнечными циклами. Это дважды рожденные, или их еще Библия называет дважды умершие. Это самое сокровенное явление природы на Земле. Раскрыты свойства человека, переведенного в третью форму жизни, указывая на его интеллектуальный уровень, чтобы понять, зачем на Земле нуждаются в его знаниях. Акцентировано, что за перевод в третью форму жизни человека на Земле, создателем нашего мира, возложена на церковь и определена ее ответственность. Библия является священной книгой христианского мира, имеет решение любой проблемы, поэтому выгоняет все проблемы в нашей жизни, дает людям надежду и уверенность в завтрашнем дне. Защищает человечество от прогресса, которого человек опасается.

Ключевые слова: Библия; Солнце; клетка; человек; жизнь; физика; эволюция; возраст; движение; материя.

\section{P. Shlapak \\ Uman National University of Horticulture, Uman, Ukraine}

\section{HUMAN LIFE ON THE EARTH IN THE CONTEXT OF MATTER MOTION AND PHYSICAL LAWS}

The author reveals the galactic circulation of organic matter, including the Solar System, in terms of the matter motion and the physical laws on the basis of the materialization of antimatter into the matter. Referring to the Bible, he shows that the life of the animal world is present on all the planets but at different levels and in different forms because the basis of the life of the animal world is the improvement of the biological cell of the higher world which has got into the Solar System to Pluto planet and, with its moving along the planets, it forms and improves itself for self-life beyond its borders. The study of the applied science of the Ancient World, which is encrypted in the Bible, was conducted; it gives an opportunity to reveal the physical phenomenon of successive twins, which is unknown to the science and the essence of which has not been disclosed. The author links the life of the organic world of the Earth to the basis of the motion of hydrogen cosmic matter and solar carbonic one, as the nature phenomena. It is noted that the hydrogen matter when moving from space along the planets of the Solar System, which are endowed with different energy density, is forced to change its polarity through the life of the animal world with moving to the Sun and supplying it with hydrogen as fuel for its vital activity. The hydrogen matter changes the polarity of matter through the life of the animal world and then only moves to a higher energy level. The carbonic matter, as a product of the synthesis process in the Sun, is carried out by quanta of light and dissipates along the planets of its system with forming the vegetable world. It is emphasized that the animal world stands at the entrance of matter to the Solar System, and the vegetable world at its exit. The article defines three forms of human life on the Earth and its physiognomic modifications depending on the levels of nuclear filling: Earth, Moon, and Solar. It is proved that an infant in the mother's womb lives energetically with the hydrogen cosmic matter, which comes to the Earth surface from the Earth core. The fetus lives and develops with this matter for 270 days. Being born, a human moves to live during natural 120 years with the carbonic solar matter, which comes to the Earth surface with the lunar cycles of the matter motion. For the first time, the essence of the third form of human life on the Earth is revealed, when a human from the age of 120 goes to live for 1,000 years with the carbonic matter, however not with the lunar cycles but with the solar ones. The properties and intellectual level of the person transferred to the third form of life transpire. It is noted that the Bible, as a guide to human life on the Earth, is a sacred book of the Christian world that solves any problem, and therefore expels all problems from our lives, gives people hope and confidence in tomorrow. It protects humanity from the progress that a person anticipates.

Keywords: the Bible; sun; cell; human; life; physics; evolution; age; motion; matter. 